\title{
Retrogressive thaw slumps temper dissolved organic carbon delivery to streams of the Peel Plateau, NWT, Canada
}

\author{
Cara A. Littlefair ${ }^{1, *}$, Suzanne E. Tank ${ }^{1}$, and Steven V. Kokelj ${ }^{2}$ \\ ${ }^{1}$ Department of Biological Sciences, University of Alberta, Edmonton, AB, T6G 2E9, Canada \\ ${ }^{2}$ Northwest Territories Geological Survey, Government of the Northwest Territories, Yellowknife, NWT, X1A 2L9, Canada \\ * previously published under the name Cara A. Bulger \\ Correspondence to: Cara A. Littlefair (cara.bulger@gmail.com)
}

Received: 6 June 2017 - Discussion started: 29 June 2017

Revised: 18 October 2017 - Accepted: 19 October 2017 - Published: 6 December 2017

\begin{abstract}
In Siberia and Alaska, permafrost thaw has been associated with significant increases in the delivery of dissolved organic carbon (DOC) to recipient stream ecosystems. Here, we examine the effect of retrogressive thaw slumps (RTSs) on DOC concentration and transport, using data from eight RTS features on the Peel Plateau, NWT, Canada. Like extensive regions of northwestern Canada, the Peel Plateau is comprised of thick, ice-rich tills that were deposited at the margins of the Laurentide Ice Sheet. RTS features are now widespread in this region, with headwall exposures up to $30 \mathrm{~m}$ high and total disturbed areas often exceeding 20 ha. We find that intensive slumping on the Peel Plateau is universally associated with decreasing DOC concentrations downstream of slumps, even though the composition of slump-derived dissolved organic matter (DOM; assessed using specific UV absorbance and slope ratios) is similar to permafrost-derived DOM from other regions. Comparisons of upstream and downstream DOC flux relative to fluxes of total suspended solids suggest that the substantial fine-grained sediments released by RTS features may sequester DOC. Runoff obtained directly from slump rill water, above entry into recipient streams, indicates that the deepest RTS features, which thaw the greatest extent of buried, Pleistocene-aged glacial tills, release low-concentration DOC when compared to paired upstream, undisturbed locations, while shallower features, with exposures that are more limited to a relict Holocene active layer, have within-slump DOC concentrations more similar to upstream sites. Finally, fine-scale work at a single RTS site indicates that temperature and precipitation serve as primary environmental controls on above-slump and below-slump
\end{abstract}

DOC flux, but it also shows that the relationship between climatic parameters and DOC flux is complex for these dynamic thermokarst features. These results demonstrate that we should expect clear variation in thermokarst-associated DOC mobilization across Arctic regions. However, they also show that within-region variation in thermokarst intensity and landscape composition is critical for determining the biogeochemical response. Geological and climate legacy shape the physical and chemical composition of permafrost and thermokarst potential. As such, these factors must be considered in predictions of land-to-water carbon mobilization in a warming Arctic.

\section{Introduction}

Anthropogenic climate change is significantly affecting the Arctic cryosphere (IPCC, 2014). Temperature increases in circumpolar regions are predicted to be at least $40 \%$ greater than the global mean, while precipitation is also expected to increase significantly in most locations (IPCC, 2014). The resulting degradation of permafrost is forecast to have wideranging effects because thawing has the potential to greatly alter the physical, chemical, and biological functioning of landscapes (Frey and McClelland, 2009; Khvorostyanov et al., 2008a, b; Kokelj et al., 2017a; Schuur et al., 2008, 2013). In particular, permafrost acts as a long-term storage medium for solutes and sediments and as a barrier to the participation of permafrost-sequestered constituents within active biogeochemical cycles (Frey and McClelland, 2009; Vonk et al., 2015a). Consequently, permafrost thaw can enhance linkages 


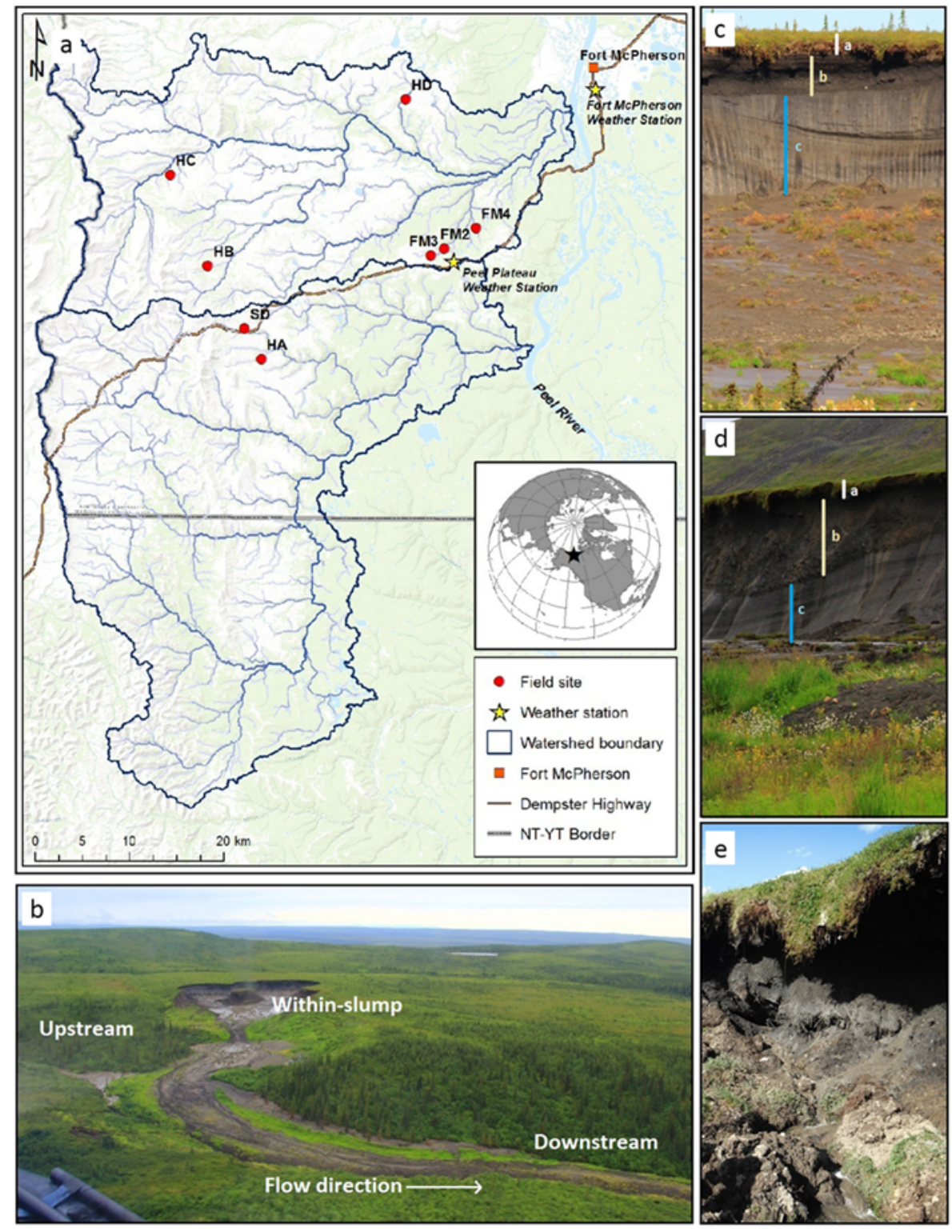

Figure 1. Location and morphometry of thaw slumps on the Peel Plateau, Northwest Territories, Canada. Panel (a) depicts the stream networks and location of the eight retrogressive thaw slumps studied. Panel (b) depicts representative sampling locations at each slump site; FM3 depicted. Panels (c)-(e) depict representative thaw slump headwall stratigraphies. Panel (c) shows a mega-slump (FM3, the smallest mega-slump, is depicted); panel (d) shows a moderate-sized slump (HB); panel (e) shows the smallest slump that was sampled (SD). In panels (c) and (d), the approximate location of the modern active layer a, early Holocene-aged paleo-thaw layer b, and Pleistocene-aged glacigenic materials c is shown. Photo credit: Scott Zolkos.

between terrestrial and aquatic systems, via increased transport of terrestrial compounds from land to water (Kokelj et al., 2013; Tanski et al., 2016; Vonk et al., 2015a). Given that circumpolar stores of permafrost carbon are estimated to be almost double that of the atmospheric carbon pool (Hugelius et al., 2014), there is great potential for large increases in carbon mobilization as a result of permafrost thaw (Schuur et al., 2015). Within this context, the mobilization of dissolved organic carbon (DOC) from previously frozen soils is of particular interest because DOC acts as the primary substrate for the microbially mediated mineralization of organic carbon to carbon dioxide (Battin et al., 2008) and serves as the primary vehicle for the delivery of terrestrial carbon to the Arctic Ocean (Dittmar and Kattner, 2003; Holmes et al., 2012; Spencer et al., 2015). As a result, the implications of thaw-mediated DOC mobilization may range from effects on the permafrost-carbon feedback to the ecological and biogeochemical functioning of streams, rivers, and the nearshore 
ocean (e.g., Fritz et al., 2017; Tank et al., 2012a; Vonk et al., 2015a).

Permafrost thaw can modify landscapes in many different ways, ranging from an increase in active-layer thickness and terrain subsidence to thermokarst features that significantly reconfigure the physical structure of landscapes (Kokelj and Jorgenson, 2013). Of these, thermokarst has the potential to rapidly expose significant quantities of previously frozen soils to biological and chemical processing (Abbott et al., 2014, 2015; Malone et al., 2013; Tanski et al., 2017). One of the most conspicuous manifestations of thermokarst is the retrogressive thaw slump (RTS; Fig. 1), which develops as a result of mass wasting in ice-rich glacial deposits across northwestern Canada, Alaska, and western Siberia (Kokelj et al., 2017a) and in Yedoma regions of Alaska and Siberia (Murton et al., 2017). Thaw slumps are widespread throughout glaciated terrain in the western Canadian Arctic (Kokelj et al., 2017a; Lantuit et al., 2012), including on the Peel Plateau (Lacelle et al., 2015). These dynamic landforms develop via the ablation of an ice-rich headwall and are particularly efficient at thawing thick zones of ice-rich permafrost and translocating large volumes of sediment from slopes to downstream environments (see Fig. 1). RTS features remain active for decades (Lantuit et al., 2012). They typically stabilize following sediment accumulation at the base of the headwall (Kokelj et al., 2015) but can reactivate, causing thaw within the scar zone and upslope expansion of the disturbance (Kokelj et al., 2013; Lantuit and Pollard, 2008). During periods of activity, thawed materials accumulate as a saturated slurry in the slump scar zone (see Fig. 1b) and are transported downslope by mass flow processes, which are accelerated by meltwater- and rainfall-induced saturation (Kokelj et al., 2015). Surface runoff can also remove solutes and suspended sediment from the thawed substrate to downstream environments. Although variation in temperature, precipitation, and solar radiation have been correlated with development rates and the growth of RTS features (Kokelj et al., 2009, 2013, 2015; Lacelle et al., 2010; Lewkowicz, 1986, 1987), we know little about how these and other environmental drivers might control permafrost-DOC dynamics on the individual-slump to small watershed scale.

On the Peel Plateau, an individual thaw slump can impact tens of hectares of terrain, displace hundreds of thousands of cubic meters of sediments, and significantly alter surface water sediment and solute loads (Kokelj et al., 2013; Malone et al., 2013) and thus downstream ecosystems (Chin et al., 2016). The magnitude of these disturbances and their cumulative impacts is great enough to alter solute loads in the Peel River (70 $000 \mathrm{~km}^{2}$ watershed area; Kokelj et al., 2013), even though only a small portion of that river's total catchment area $(<1 \%)$ is influenced by thermokarst (Kokelj et al., 2017b; Segal et al., 2016). This contrasts with many other thaw-affected regions, where increases in solute loads following permafrost disturbance can be transient and have little overall effect on annual solute fluxes (e.g., in High Arc- tic regions affected by active-layer detachments; Lafrenière and Lamoureux, 2013). In addition, permafrost thaw on the Peel Plateau is notable in that it exposes large quantities of mineral-rich glacial till, which is overlain by a relatively shallow layer of slightly more organic-rich soils (Duk-Rodkin and Hughes, 1992; Kokelj et al., 2017b). Although this tillassociated, RTS-susceptible landscape type is found across the Laurentide and Barents-Kara glacial margins of Canada, Alaska, and Siberia (Kokelj et al., 2017a), it contrasts with regions of Alaska and eastern Siberia that are either yedomarich or were covered by patchy or thin drift during the late Pleistocene. It is these latter regions that have been a focus for the study of permafrost-DOC interactions to date (Abbott et al., 2014, 2015; Drake et al., 2015; Mann et al., 2012; Vonk et al., 2013).

Permafrost thaw has been documented to enhance DOC concentrations in recipient aquatic ecosystems in several Arctic regions (Frey and McClelland, 2009; Tank et al., 2012b; Vonk and Gustafsson, 2013). In Alaska, streams affected by thaw slumps have higher DOC concentrations than unaffected systems across various terrain types (2-3-fold increase; Abbot et al., 2014), while in eastern Siberia the DOC concentration in runoff from thawing yedoma is considerably greater than concentrations in recipient river systems ( $\sim 30$-fold elevation; Spencer et al., 2015). However, multiple factors, including variable carbon content in permafrost soils (Hugelis et al., 2014) and variation in ground ice type and volume (Fritz et al., 2015), may affect DOC release from permafrost. In regions where thermokarst transports fine-grained sediments to aquatic systems, sorption processes may also be important because dissolved organic matter (DOM) can readily sorb to mineral soils (e.g., Kothawala et al., 2009). Sorption to mineral sediments can cause DOM to be rapidly removed from solution in stream systems (Kaiser and Guggenberger, 2000; Kothawala et al., 2009; McDowell, 1985), while enabling the downstream transport and continued sequestration of organic carbon (Hedges et al., 1997). This process may be particularly important for regulating DOC dynamics in glacial margin landscapes, where a predisposition to thaw slumping results in an abundance of thermokarst-related slope disturbances which mobilize fine-grained glacial sediment stores to downstream systems (Kokelj et al., 2017a, b; Lantuit et al., 2012; Rampton, 1988). Despite this, we know little about the downstream consequences of permafrost thaw for carbon biogeochemistry in till-dominated glacial landscapes, which are emerging as some of the most geomorphically dynamic permafrost environments in the circumpolar Arctic.

The objective of this study was to quantify how RTS features affect the concentration and composition of DOC across a series of slump-affected streams on the Peel Plateau and to examine how observed variation in slump morphometry affects DOC dynamics in downstream environments. We further investigated how short-term variation in precipitation, temperature, and solar radiation affect DOC delivery from 
land to water, using measurements of DOC flux above and below a single RTS feature. We targeted the thermokarstsensitive Peel Plateau for this work, which shares similarities with till-rich, glacial margin landscapes throughout Canada, Alaska, and Siberia (Kokelj et al., 2017a). By comparing our results to those from elsewhere, we highlight how broad variation in permafrost soil composition, permafrost genesis, and Quaternary history influence variation in land-freshwater DOC dynamics across divergent regions of the warming circumpolar Arctic.

\section{Study site}

\subsection{General study site description}

Our study was conducted on the Peel Plateau, situated in the eastern foothills of the Richardson Mountains, NWT, Canada, in the zone of continuous permafrost (Fig. 1a). The fluvially incised plateau ranges in elevation from 100 to $650 \mathrm{~m}$ above sea level. The region was covered by the Laurentide Ice Sheet (LIS) for a brief period (a maximum of 2000-3000 years) 18500 cal yr BP (Lacelle et al., 2013). The bedrock of the region is Lower Cretaceous marine shale from the Arctic River formation (Norris, 1984) and siltstone overlain by Late Pleistocene glacial, glaciofluvial, and glaciolacustrine sediments (Duk-Rodkin and Hughes, 1992). These Pleistocene deposits host ice-rich permafrost, overlain by a shallow and commonly organic-rich active layer. Radiocarbon dating in the region has placed the age of relict ground ice in the late Pleistocene (18 $100 \pm 60{ }^{14} \mathrm{C}$ yr BP; Lacelle et al., 2013). Upper layers of permafrost thawed during the early Holocene and host younger, Holocene-aged organic materials (Lacelle et al., 2013). These are distinguished from deeper Pleistocene-aged permafrost by a thaw unconformity (Burn, 1997; Fig. 1), which developed when warmer climate during the early Holocene prompted the thawing of near-surface permafrost. The regional increase in active-layer thickness and debris flow on sloping terrain integrated organic matter into the thawed soils and enabled the leaching of soluble ions (see Fig. 1c-d). Climate cooling and permafrost aggradation have archived this notable stratigraphic variation in geochemistry, organic matter content, and cryostructure (Burn, 1997; Fritz et al., 2012; Kokelj et al., 2002; Lacelle et al., 2014; Murton and French, 1994).

Ice-marginal glacigenic landscapes such as the Peel Plateau host thick layers of ice-rich sediments and thus have a predisposed sensitivity to climate-driven thaw slump activity (Kokelj et al., 2017b). On the Peel Plateau, slumping is largely constrained by the maximum extent of the LIS because the thick layers of ice-rich permafrost necessary for RTS activity are typically not present beyond the glacial limits (Lacelle et al., 2015). Fluvial incision provides the topographic gradient necessary for thaw slump development and RTS features are common; ranging in size from numerous small features to those greater than 20 ha, which are rare $(<5 \%$ prevalence; Lacelle et al., 2015). The recent intensification of slumping on the Peel Plateau is driven in part by increasing air temperatures and summer rainfall (Kokelj et al., 2015). This intensification is also increasing the thaw of the deepest layer of ice-rich, organic-poor, Pleistocene-aged glacigenic tills that underlie this region. The pattern of abundant thaw slump development throughout ice-marginal glaciated permafrost landscapes extends from the Peel Plateau across the western Canadian Arctic and persists on continental scales (Kokelj et al., 2017a).

\subsection{Regional climate}

The regional climate is typical of the subarctic with long, cold winters and short, cool summers. Mean annual air temperature (1981-2010) at the Fort McPherson weather station (Fig. 1a) is $-7.3^{\circ} \mathrm{C}$, with average summer (June-August) temperatures of $13.3^{\circ} \mathrm{C}$ (Environment Canada, 2015). A warming trend of $0.77^{\circ} \mathrm{C}$ per decade since 1970 has been recorded; however, these increases are most apparent in the winter months (Burn and Kokelj, 2009). Our sample period spanned the thaw months of July and August; average 1981-2010 temperatures for those months, recorded at Fort McPherson, are 15.2 and $11.8^{\circ} \mathrm{C}$, respectively, similar to temperatures at Fort McPherson during 2014 (15.6 and $11.6^{\circ} \mathrm{C}$ ) but slightly higher than 2014 averages observed at a recently established meteorological station on the Peel Plateau (Fig. 1a; $13.2^{\circ} \mathrm{C}$ in July and $9.5^{\circ} \mathrm{C}$ in August). Annual cumulative rainfall (1981-2010) at Fort McPherson averages $145.9 \mathrm{~mm}$, with July and August having the highest rainfall levels at 46.4 and $39.1 \mathrm{~mm}$ (Environment Canada, 2015). In 2014, rainfall for July and August was 71 and $121 \mathrm{~mm}$ at Fort McPherson and 128.7 and $170.7 \mathrm{~mm}$ on the Peel Plateau. This continues the trend for this region of increasingly wet summers with numerous extreme rainfall events (Kokelj et al., 2015).

\section{Methods}

\subsection{Slump site selection}

Eight RTS features were selected from across the study region, using aerial surveys and previous knowledge of the region (Figs. 1, S1 in the Supplement; Table 1). Selected slumps were characterized by a debris tongue that connected the slump to the valley bottom and directly impacted a stream channel. Sampling at each slump occurred at three discrete locations: upstream, within-slump, and downstream of slump influence (Fig. 1b). Upstream sites were trunk streams that connected with the slump flow path further downstream and were unaffected by any active geomorphic disturbances and thus representative of an undisturbed, pristine environment. Within-slump sampling occurred at points of channelized slump runoff within the scar zone or upper debris tongue. 
Table 1. Slump characteristics and sampling information for eight retrogressive thaw slumps sampled during the 2014 field season on the Peel Plateau, NWT, Canada. Characteristics are derived from published values and field estimations.

\begin{tabular}{lrccrrr}
\hline $\begin{array}{l}\text { Slump } \\
\text { location }\end{array}$ & $\begin{array}{r}\text { Sample dates } \\
\text { (Julian day) }^{\mathrm{a}}\end{array}$ & Latitude & Longitude & $\begin{array}{r}\text { Area } \\
\text { (ha) }\end{array}$ & $\begin{array}{r}\text { Debris } \\
\text { tongue }(\mathrm{m})\end{array}$ & $\begin{array}{r}\text { Headwall } \\
\text { height }(\mathrm{m})\end{array}$ \\
\hline FM4 & $202,210,223$ & $67^{\circ} 16.679^{\prime}$ & $-135^{\circ} 09.573^{\prime}$ & 8.8 & 960 & 16 to $20^{\mathrm{d}}$ \\
FM2 & $200,209,222$ & $67^{\circ} 15.462^{\prime}$ & $-135^{\circ} 14.216^{\prime}$ & 31.7 & 1529 & $25^{\mathrm{e}}$ \\
FM3 & 197,212 & $67^{\circ} 15.100^{\prime}$ & $-135^{\circ} 16.270^{\prime}$ & 6.1 & 576 & $10^{\mathrm{e}}$ \\
SD & $196,213,234$ & $67^{\circ} 10.818^{\prime}$ & $-135^{\circ} 43.630^{\prime}$ & 3.3 & NA & $2-4^{\mathrm{d}}$ \\
HA & 190,229 & $67^{\circ} 09.057^{\prime}$ & $-135^{\circ} 41.121^{\prime}$ & 5.9 & 288 & $6-10^{\mathrm{d}}$ \\
HB & 190,229 & $67^{\circ} 14.397^{\prime}$ & $-135^{\circ} 49.167^{\prime}$ & $13.6^{\mathrm{c}}$ & 257 & $6-10^{\mathrm{d}}$ \\
HC & 190,229 & $67^{\circ} 19.652^{\prime}$ & $-135^{\circ} 53.620^{\prime}$ & $10.3,10.3^{\mathrm{c}}$ & 408 & $6-10^{\mathrm{d}}$ \\
HD & 190,229 & $67^{\circ} 24.025^{\prime}$ & $-135^{\circ} 20.048^{\prime}$ & 1.8 & 137 & $6-10^{\mathrm{d}}$ \\
Weather Station & & $67^{\circ} 14.756^{\prime}$ & $-135^{\circ} 12.920^{\prime}$ & & & \\
\hline
\end{tabular}

a Excludes samples for the FM3 "environmental controls" analysis which was conducted on 17 additional dates; HD: Julian date 229 did not include a within-slump sample. ${ }^{\mathrm{b}}$ The length of debris tongue measured from the base of the debris scar, along the valley bottom stream. ${ }^{\mathrm{c}}$ Site HB is comprised of two smaller slump features that have merged into the scar zone delineated here; site HC is comprised of five separate slump features that have merged into two scar zones, each with an area of $10.3 \mathrm{ha} .{ }^{\mathrm{d}}$ Rough estimates by field crews over 2014 and 2015 field seasons.

e Kokelj et al. (2015).

Downstream sampling locations were below the confluence of the sampled upstream flow and all within-slump runoff paths and were chosen to be representative of slump impact on aquatic ecosystems across the Peel Plateau landscape. In one instance (Slump HD, 17 August), a fluidized flow event between sampling saturated the scar zone and obliterated within-slump channelized surface flow. As a result, the within-slump sample taken at this site was not representative of typical channelized slump runoff that characterized all other slump sampling conditions and has been discarded from all analyses.

A general classification of the slumps is difficult as these features are influenced by a diverse range of geomorphic processes that vary in intensity over time (Table 1; Fig. S1). Three of the slumps (FM4, FM2, FM3) are classified as "mega-slumps", characterized by areas greater than 5 ha, a headwall greater than $4 \mathrm{~m}$ in height, and a debris tongue that connects the slope to the valley below (Kokelj et al., 2013, 2015). Of these, FM4 possesses a headwall approximately $20 \mathrm{~m}$ in height but was largely stabilized in 2014 (Fig. S1). FM2 is among the largest active slumps in the region, with a headwall $25-30 \mathrm{~m}$ high and visible as a much smaller feature in air photos since 1944 (Lacelle et al., 2015). Slump FM3, which was the focus for "environmental controls" work (further described below), covers an area of approximately 10 ha with a headwall of approximately $10 \mathrm{~m}$ height and a debris tongue that extends nearly $600 \mathrm{~m}$ down valley (Table 1). The headwall retreat rate at FM3 over a 20-year period has been calculated at $12.5 \mathrm{~m} \mathrm{yr}^{-1}$ (Lacelle et al., 2015). FM2 and FM3 geochemistry and geomorphology were previously described by Malone et al. (2013). SD is the smallest and youngest slump that we studied and was initiated when the diversion of a small creek caused lateral bank erosion. In 2014, the SD headwall was 2-4 m high with no defined debris tongue and a scar zone extending approximately $20 \mathrm{~m}$ upslope. The remaining slump sites (HA, HB, HC, HD) were all well-developed active RTS features with headwalls similar to, or smaller than, FM3 but with smaller debris tongues (Table 1). With the exception of SD, slump headwalls exposed permafrost well below a thaw unconformity, indicating that Pleistocene-aged, unweathered glacigenic materials were being thawed (Lacelle et al., 2013).

\subsection{Field sampling and data collection}

\subsubsection{The effect of slumping on DOC and stream water chemistry}

The majority of our sampling was conducted during the summer of 2014. Of the eight slumps that were sampled, three were accessed from the Dempster Highway three times over the sampling season, one (FM3; see also Sect. 3.2.2) was accessed twice from the highway, and four were accessed twice via helicopter (Table 1). At each of the upstream, downstream, and within-slump sampling locations, specific conductivity, $\mathrm{pH}$, and temperature were recorded using a YSI Pro Plus multiparameter meter. Water samples were collected from directly below the stream surface into $1 \mathrm{~L}$ acid-washed HDPE bottles and allowed to sit in chilled, dark conditions for $24 \mathrm{~h}$ to enable the considerable sediments in these samples to partially settle out of suspension. Sample water was then filtered with precombusted $\left(475^{\circ} \mathrm{C}, 4 \mathrm{~h}\right)$ Whatman $\mathrm{GF} / \mathrm{F}$ filters $(0.7 \mu \mathrm{m}$ pore size $)$. Filtered sample water was transferred into $40 \mathrm{~mL}$ acid-washed, precombusted glass bottles for DOC analysis or $60 \mathrm{~mL}$ acid-washed HDPE bottles for the analysis of absorbance and major ions. DOC samples were acidified with hydrochloric acid $\left(1 \mu \mathrm{LL}^{-1}\right)$, following Vonk et al. (2015b). The GF/F filters were retained for analysis of total suspended solids (TSS). Samples for stable water isotopes were collected directly from streams into acid- 
washed $40 \mathrm{~mL}$ HDPE bottles with no headspace and sealed. During summer 2016, samples were additionally collected from a subset of slump locations (FM2, FM3, FM4, and SD) for the ${ }^{14} \mathrm{C}$ signature of DOC at upstream and within-slump sites. $\mathrm{DO}^{14} \mathrm{C}$ samples were collected in acid-washed polycarbonate bottles, allowed to settle for $24 \mathrm{~h}$, and filtered using precombusted Whatman GF/F filters into precombusted glass media bottles with phenolic screw caps and butyl septa. All samples were refrigerated until analysis. Absorbance samples were analyzed within 1 week of collection, cation samples within 4 months of collection, and DOC (including ${ }^{14} \mathrm{C}$ ) samples within 1-2 months of collection. Samples for $\mathrm{Fe}$ and $\delta^{18} \mathrm{O}$ were analyzed within 6 months of collection.

\subsubsection{Environmental controls on DOC flux}

To explore how environmental variables control the flux of DOC from RTS-affected streams, we visited slump FM3 an additional 17 times beyond the sampling described above. This intensively studied site was chosen to be representative of active Peel Plateau slumps that are eroding Holocene- to Pleistocene-aged sediments. During each visit, we measured discharge at the upstream and downstream locations to calculate DOC flux and collected upstream and downstream DOC concentration samples. Downstream discharge was measured using an OTT C2 current meter at three locations across the small stream and at $40 \%$ depth. Due to the shallow, low flow conditions at the upstream site, upstream discharge was measured using the cross-sectional method (Ward and Robinson, 2000). In both cases, discharge was calculated as the product of velocity and stream cross-sectional area. Local daily climate data were obtained from an automated meteorological station established in 2010 by the Government of the Northwest Territories (Kokelj et al., 2015). The station is located within $2 \mathrm{~km}$ of slump FM3 (Fig. 1a) and is instrumented for the measurement of air temperature, rainfall, and net radiation.

\subsection{Laboratory analyses}

\subsubsection{Major ions, dissolved organic carbon, $\delta^{18} \mathrm{O}$, and $\mathrm{DO}^{14} \mathrm{C}$}

Cation concentrations $\left(\mathrm{Ca}^{2+}, \mathrm{Mg}^{2+}, \mathrm{Na}^{+}\right)$were analyzed on a Perkin Elmer Analyst 200 atomic absorption spectrometer at York University. A subset of collected samples were analyzed for total dissolved $\mathrm{Fe}$ at the University of Alberta on an inductively coupled plasma - optical emission spectrometer (Thermo Scientific ICAP6300) to allow for the correction of our specific UV absorbance results (see below). DOC samples were analyzed on a Shimadzu TOC-V analyzer; DOC was calculated as the mean of the best three of five injections with a coefficient of variation of $<2 \%$; the precision of a $10 \mathrm{mg} \mathrm{L}^{-1}$ caffeine standard across all sample runs was $0.32 \mathrm{mg} \mathrm{L}^{-1}$. A Picarro liquid water isotope analyzer was used to measure $\delta^{18} \mathrm{O}$ at the University of Alberta, following filtration $(0.45 \mu \mathrm{m}$ cellulose acetate, Sartorius) into $2 \mathrm{~mL}$ autosampler vials (National Scientific), without headspace. The precision of our $\delta^{18} \mathrm{O}$ analysis is $\pm 0.2 \%$. The radiocarbon signature of DOC was measured following extraction and purification at the A.E. Lalonde AMS facility (University of Toronto) using a 3MV tandem accelerator mass spectrometer (High Voltage Engineering) following established methodologies (Lang et al., 2016; Palstra and Meijer, 2014; Zhou et al., 2015), and is reported with an error estimate of $1 \sigma$.

\subsubsection{Total suspended solids}

Samples for TSS were filtered in the field for later analysis, ensuring that there was enough sediment on the precombusted $\left(475^{\circ} \mathrm{C}, 4 \mathrm{~h}\right)$ and pre-weighed $\mathrm{GF} / \mathrm{F}$ filters. Filters were stored frozen, dried at $60^{\circ} \mathrm{C}$ for $8 \mathrm{~h}$, placed in a desiccator overnight, and promptly weighed. TSS were calculated as the difference in filter weight before and after sediment loading, divided by volume filtered.

\subsubsection{Dissolved organic matter spectral characteristics}

DOM composition was assessed using absorbance-based metrics. A $5 \mathrm{~cm}$ quartz cuvette was used to obtain UVvisible spectra data from 250 to $750 \mathrm{~nm}$, using a Genesys $10 \mathrm{UV}-\mathrm{Vis}$ spectrophotometer. A baseline correction was applied to eliminate any minor interference from particles $<0.7 \mu \mathrm{m}$ (Green and Blough, 1994). Specific UV absorbance at $254 \mathrm{~nm}\left(\mathrm{SUVA}_{254}\right)$, which is correlated with DOM aromaticity (Weishaar and Aiken, 2003), was calculated by dividing the decadal absorbance at $254 \mathrm{~nm}\left(\mathrm{~m}^{-1}\right)$ by the DOC concentration $\left(\mathrm{mg} \mathrm{L}^{-1}\right)$. $\mathrm{SUVA}_{254}$ values were corrected for $\mathrm{Fe}$ interference following Poulin et al. (2014) using maximum $\mathrm{Fe}$ concentrations from laboratory analyses or as reported in Malone et al. (2013). Spectral slopes between 275 and 295 and between 350 and $400 \mathrm{~nm}\left(S_{275-295}, S_{350-400}\right)$ were calculated following Helms et al. (2008) and are reported as positive values to adhere to mathematical conventions. Slope ratios $\left(S_{\mathrm{R}}\right)$, which correlate with DOM molecular weight (Helms et al., 2008), were calculated as the ratio of $S_{275-295}$ to $S_{350-400}$.

\subsection{Statistical analyses and calculations}

Statistical analyses were completed in $\mathrm{R}$ version 3.1.3 ( $\mathrm{R}$ Core Team, 2015) using the packages "nlme" (Pinheiro et al., 2015), "Imtest" (Zeileis and Hothorn, 2002), "ImSupport" (Curtin, 2015), "car" (Fox and Weisberg, 2011), and "zoo" (Zeileis and Grothendieck, 2005). The effect of slumping on stream chemistry and optical characteristics was assessed using linear mixed-effects models in the "nlme" package of R. For each parameter, analyses were split into two separate models that included data for upstream and downstream chemistry and upstream and within-slump chemistry. 
We used this approach to separately assess the effects of slumping downstream of slump systems and to compare the composition of slump runoff to nearby, pristine environments. For each analysis, we included slump location (see Table 1) as a random effect and considered models that either nested Julian date within the random effect of slump location or allowed Julian date to occur as a fixed effect. The best model was chosen using the Akaike information criterion (AIC), and best-fit models were refit with a variance structure to ensure that model assumptions were met. The variance structures varIdent (for within-slump site and slump location) and varFixed (for Julian date) were used together (using varComb) and in isolation for this purpose (Zuur et al., 2009). AIC values for the weighted and unweighted models were again compared to choose a final model of best fit for each analysis.

We used the high-frequency data from slump FM3 to assess how environmental conditions (rainfall, temperature, solar radiation) and TSS affect DOC delivery to slump-affected streams. To do this, we conducted multiple linear regressions, using AIC values to determine models of best fit (Burnham and Anderson, 2002). To enable a specific assessment of environmental controls on downstream DOC flux, upstream DOC flux was separated out into a distinct regression analysis: upstream DOC flux was strongly correlated with flux downstream and therefore overwhelmed all environmental variables in the downstream model. Models were tested for serial correlation using the autocorrelation function, and models with variance inflation factors greater than 10 or significant Durbin-Watson test results (indicative of correlated variables; Durbin and Watson, 1950; Hair et al., 1995) were discarded. Residuals were examined to ensure the model was a good fit for the data (Zuur et al., 2009). We considered both time of sampling $(0 \mathrm{~h})$ and past $(48,72$, and $120 \mathrm{~h})$ environmental conditions in our analyses. Because cumulative values for environmental variables (i.e., accumulated rainfall in the previous 48,72 , and $120 \mathrm{~h}$ ) showed a strong positive correlation to one another, we used temporally shifted data (i.e., rainfall 48,72 , and $120 \mathrm{~h}$ prior to the DOC flux measurement) in the final model. Similar models were also constructed to examine the effects of environmental drivers on DOC concentration. Differences in paired upstream-downstream measures of DOC flux and concentration at slump FM3 were also assessed using a Wilcoxon signed rank test, a nonparametric analog to the paired- $t$ test.

Following our finding of decreasing DOC concentrations downstream of slumps (see Sects. 4.1 and 5.1), we used data from slump FM3, where we have upstream, downstream, and within-slump DOC concentration measurements, and upstream and downstream discharge measurements, to calculate a mass balance for DOC across the three sampling locations. These data - available for all three locations on two dates during the summer of 2014 were used to calculate DOC flux at upstream and downstream sites as flux $_{\text {DOCdown }}=[D O C]_{\text {down }} \cdot$ discharge $_{\text {down }}$
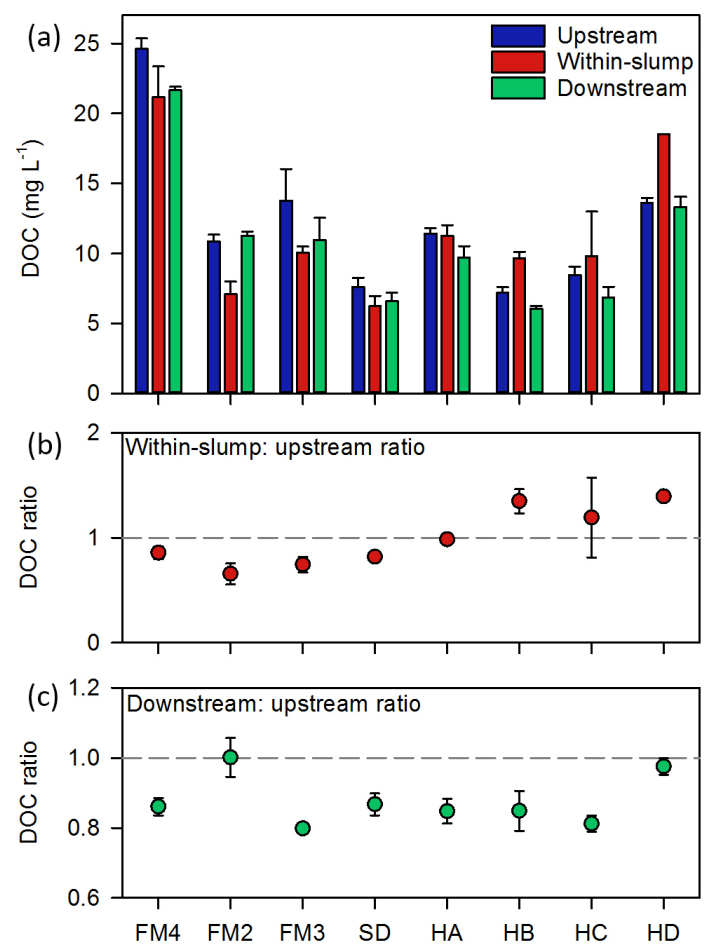

Figure 2. The effect of retrogressive thaw slumps on stream water dissolved organic carbon (DOC) concentration. Each data point represents the mean and standard error of measurements across all sampling dates, as described in Table 1. Panels (b) and (c) show the ratio of within-slump : upstream and downstream : upstream DOC concentrations within individual slumps, with points indicating the mean and standard error of this ratio across sample dates.

or flux $_{\text {DOCup }}=[\mathrm{DOC}]_{\mathrm{up}} \cdot$ discharge $_{\mathrm{up}}$ and at within-slump sites as flux $_{\mathrm{DOC} w i t h i n}=[\mathrm{DOC}]_{\mathrm{within}} \cdot\left(\right.$ discharge $_{\text {down }}-$ discharge $_{\text {up }}$ ). We calculate a similar mass balance for TSS, which we use as a rough tracer for the inflow of slump runoff over the $<1 \mathrm{~km}$ span between upstream and downstream locations at this site.

\section{Results}

\subsection{DOC concentration across slump sites}

While DOC concentrations ranged broadly across pristine streams on the Peel Plateau (Fig. 2; from 5.4 to $26.1 \mathrm{mg} \mathrm{L}^{-1}$ at upstream, pristine sites), concentrations consistently declined downstream of slumps, when compared to paired, upstream locations $(p<0.001$; Fig. 2 ; Table 2). Although this effect was modest (typically less than $20 \%$; Fig. 2), it occurred reliably across all slump sites. In contrast, comparisons of upstream and within-slump sites showed no consistent trend in DOC concentration, when evaluated across all slump locations ( $p=0.153$; Fig. 2 ; Table 2$)$. Instead, the effects of slumping on the DOC concentration of slump runoff varied by site. At the largest, best-developed slump 
Table 2. Results of the mixed-effects models used to assess the effects of slumping on stream water chemistry and optical characteristics. Downstream models incorporated data from downstream and upstream sites; within-slump models incorporated data from within-slump and upstream sites. Provided are degrees of freedom (df), $t$ statistics, and $p$ values for individual model runs. Further details on the statistical approach are provided in Sect. 3.4.

\begin{tabular}{lrrrrrrrr}
\hline & \multicolumn{3}{c}{ Downstream } & & \multicolumn{3}{c}{ Within-slump } \\
\cline { 2 - 3 } \cline { 7 - 9 } & df & $t$ & $p$ & & df & $t$ & $p$ \\
\hline DOC & 20 & -12.895 & $<0.001$ & & 30 & -1.468 & 0.153 \\
$\mathrm{Na}$ & 33 & 9.662 & $<0.001$ & & 30 & 7.278 & $<0.001$ \\
$\mathrm{Ca}$ & 33 & 9.767 & $<0.001$ & & 30 & 4.782 & $<0.001$ \\
Mg & 33 & 6.166 & $<0.001$ & & 30 & 8.593 & $<0.001$ \\
Conductivity & 32 & 43.083 & $<0.001$ & & 30 & 11.895 & $<0.001$ \\
TSS & 29 & 6.692 & $<0.001$ & & 28 & 2.187 & 0.037 \\
SUVA & 32 & -4.460 & $<0.001$ & & 30 & -35.052 & $<0.001$ \\
$S_{\mathrm{R}}$ & 32 & 5.333 & $<0.001$ & & 31 & 8.065 & $<0.001$ \\
$S_{275}$ & 31 & 2.856 & 0.008 & & 31 & 8.159 & $<0.001$ \\
$S_{350}$ & 32 & -2.196 & 0.036 & & 31 & 16.665 & $<0.001$ \\
\hline
\end{tabular}

complexes (FM4, FM2, and FM3), where debris tongues are extensive and thaw extends well into the deepest layer of Pleistocene-aged glacigenic materials, DOC concentrations tended to be lower in slump runoff than at the paired upstream sites (Fig. 2). At more modestly sized slumps (HB, $\mathrm{HC}$, and $\mathrm{HD}$ ), where the modern active layer and paleothaw layer comprise a greater proportion of thawed materials, within-slump DOC concentrations tended to be higher than values upstream (Fig. 2). Within each site, DOC concentrations were relatively consistent across the two to three sampling periods (Fig. 2).

\subsection{Bulk chemistry of pristine waters and slump runoff}

To better understand how the input of slump runoff affects downstream DOC, we examined concentrations of major ions, conductivity, and TSS as "tracers" of slump activity because these constituents have previously been shown to be significantly affected by slumping in this region (Kokelj et al., 2005, 2013; Malone et al., 2013; Thompson et al., 2008). Major ion $\left(\mathrm{Ca}^{2+}, \mathrm{Mg}^{2+}, \mathrm{Na}^{+}\right)$concentrations in slump runoff were considerably greater than in pristine streams (a 2.7- to 11.7-fold increase; Fig. 3b-d; Table 2). These patterns were similar, though muted, at slump-affected downstream sites, where major ion concentrations were 1.5- to 3.5fold greater than at pristine sites (Fig. 3b-d; Table 2). Mean conductivity also increased significantly as a result of slumping $(p<0.001$; Table 2$)$ : within-slump sites had conductivity values that were 9.2-fold greater than upstream sites, while downstream values were an average of 2.6 times greater than those upstream (Fig. 3e). Finally, TSS were also significantly elevated at slump-affected sites $(p<0.001$; Table 2$)$ with concentrations being more than 2 orders of magnitude greater within slumps and more than 1 order of magnitude greater downstream when compared to upstream sites (Fig. 3a). The effect of slump runoff on downstream chemistry is also re- flected in DOC: ion and DOC: TSS ratios, which decreased markedly between upstream and downstream locations. For example, molar ratios of $\left(\mathrm{Ca}^{2+}+\mathrm{Mg}^{2+}\right)$ : DOC averaged $0.78 \pm 0.37$ (mean \pm standard error) upstream of slumps but $2.07 \pm 0.45$ downstream, while average gram-weight ratios of TSS : DOC were $32 \pm 12$ upstream but $1454 \pm 332$ at downstream locations.

\subsection{Spectral and isotopic characteristics}

$\mathrm{SUVA}_{254}$, which is positively correlated with DOM aromaticity (Weishaar and Aiken, 2003), was significantly lower within slumps and downstream of slumps than in upstream, pristine environments ( $p<0.001$; Fig. 4 ; Table 2$)$. Mean within-slump SUVA $_{254}$ was less than half of that observed for pristine waters (Fig. 4), while downstream values declined by approximately $20 \%$. In accordance with the SUVA $_{254}$ results, $S_{275-295}, S_{350-400}$, and $S_{\mathrm{R}}$ were all significantly greater within slumps when compared to upstream sites ( $p<0.001$; Fig. 4; Table 2), indicating lower DOM molecular weight within slumps (Helms et al., 2008). Differences in slope parameters between upstream and downstream locations were muted relative to the within-slumpupstream comparisons (Fig. 4), with $S_{275-295}(p=0.008)$ and $S_{\mathrm{R}}(p<0.001)$ increasing significantly, but more modestly, downstream of slumps and $S_{350-400}$ declining slightly ( $p=0.036$; Fig. 4; Table 2).

Upstream $\delta^{18} \mathrm{O}$ averaged $-20.1 \% \circ \pm 0.12$, which corresponds to a modern active-layer pore water $\delta^{18} \mathrm{O}$ signature for this region (Lacelle et al., 2013; Fig. 5). Within-slump $\delta^{18} \mathrm{O}$ was discernibly depleted when compared to upstream locations, with mean values of $-22.7 \% \circ \pm 0.72$, which falls between previously identified regional end-members for Pleistocene-aged ground ice (18 $\left.100 \pm 60{ }^{14} \mathrm{C} \mathrm{yr} \mathrm{BP}\right)$ and the modern active layer (Lacelle et al., 2013; Fig. 5). Withinslump $\delta^{18} \mathrm{O}$ was also much more variable between RTS fea- 

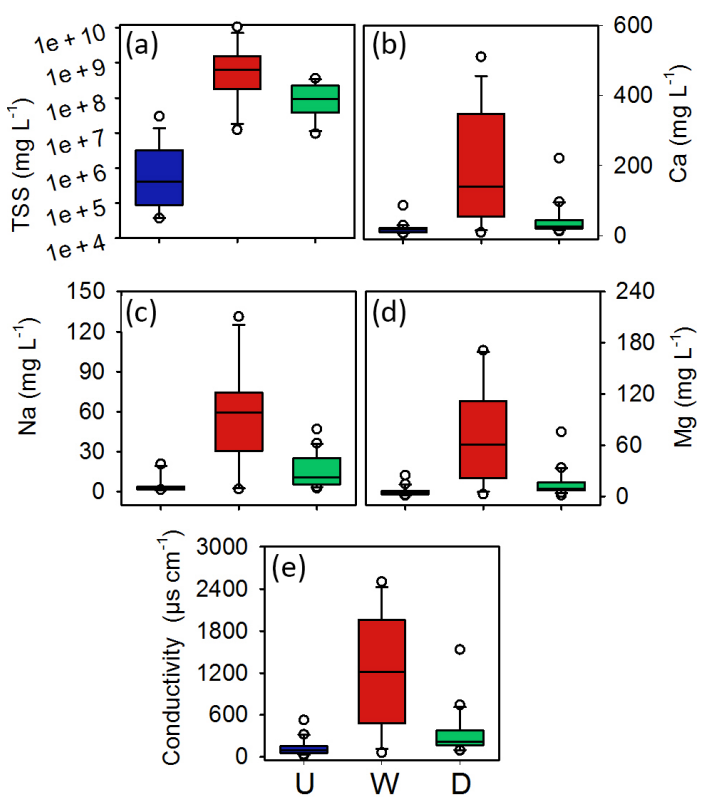

Figure 3. Box and whisker plots to illustrate the effects of retrogressive thaw slump activity on stream geochemistry. Each box plot includes data from across all slumps and sampling periods, and indicates median values, 25th and 75th percentiles (box extremities), 10th and 90th percentiles (whiskers), and outlier points. U: upstream sites; W: within-slump sites; D: downstream sites.

tures than upstream and downstream $\delta^{18} \mathrm{O}$ values. Similar to upstream sites, downstream $\delta^{18} \mathrm{O}$ clustered near the modern active-layer $\delta^{18} \mathrm{O}$ end-member but with a small depletion that was consistent with a contribution from slump inflow $(-20.7 \% \circ \pm 0.21)$.

To further investigate the effect of water source on DOM composition, we examined the relationship between $\mathrm{SUVA}_{254}$ and $\delta^{18} \mathrm{O}$. More depleted samples taken from within-slump sites had clearly depressed $\mathrm{SUVA}_{254}$ values when compared to samples with more enriched $\delta^{18} \mathrm{O}$ (Fig. 5). Of the large, most well-developed slumps that were identified in Sect. 4.1, two (FM2 and FM3), in addition to site HB, had $\delta^{18} \mathrm{O}$ values that were more depleted than the Holocene-aged icy diamicton values reported in Lacelle et al. (2013), suggesting some contribution of runoff from older, Pleistoceneaged permafrost (Fig. 5). It is likely that the $\delta^{18} \mathrm{O}$ signal at the relatively stable mega-slump site (FM4) was somewhat diluted by the $7.2 \mathrm{~mm}$ of rainfall that fell in the $48 \mathrm{~h}$ preceding our sample. Although sites FM3 and SD received 12.4 and $3.5 \mathrm{~mm}$ of rain, respectively, in the $48 \mathrm{~h}$ prior to sampling, these are highly active slumps and thus less prone to dilution of the slump outwash signature. There was no significant rainfall immediately preceding sampling at any other sites.

The radiocarbon signature of DOC from upstream and within-slump locations at sites FM4, FM2, FM3, and SD largely mirrors the $\delta^{18} \mathrm{O}$ results. DOC from sites upstream
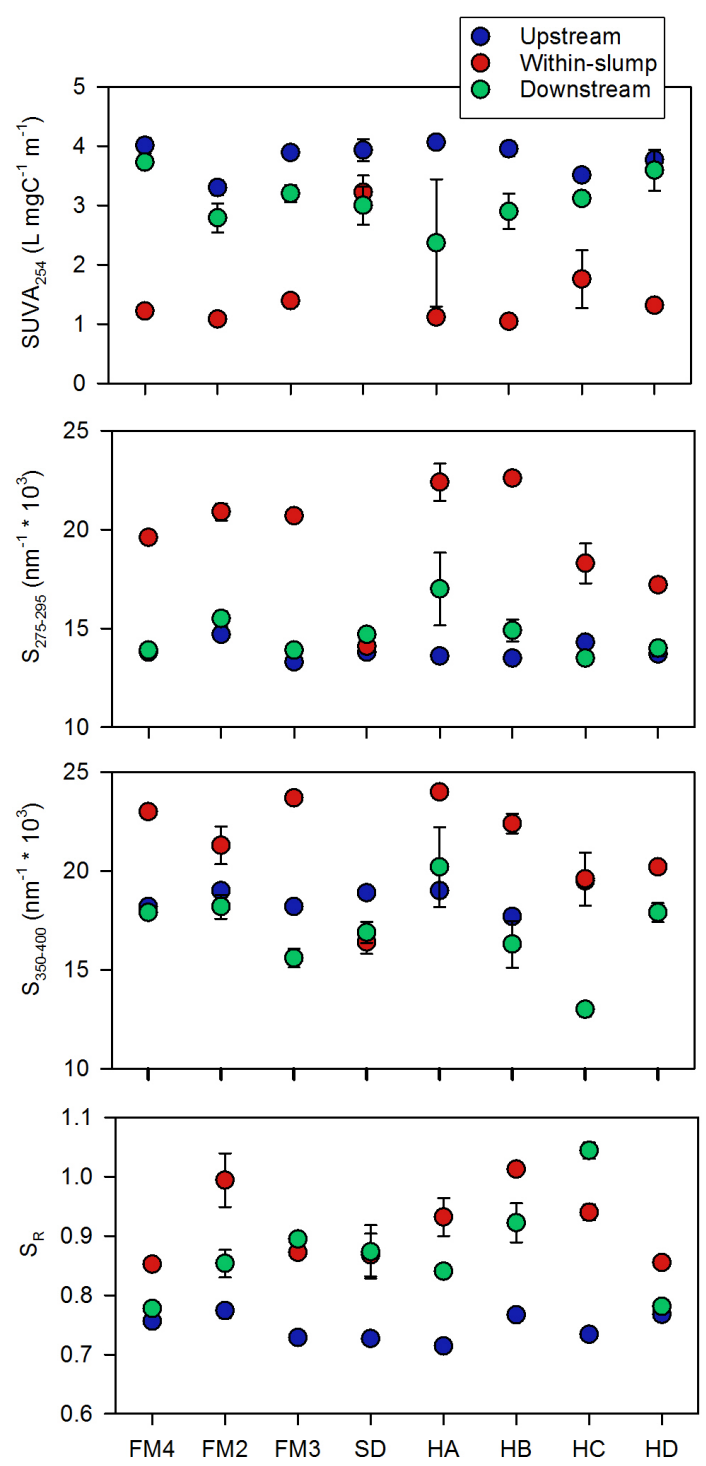

Figure 4. The effect of retrogressive thaw slumps on the optical properties of stream water dissolved organic matter. Each data point represents the mean and standard error of measurements across all sampling dates, as described in Table 1. Shown are specific UV absorbance $\left(\mathrm{SUVA}_{254}\right)$, spectral slopes between $275-295$ and 350$400 \mathrm{~nm}\left(S_{275-295} ; S_{350-400}\right)$, and the slope ratio $\left(S_{\mathrm{R}}\right)$.

of slump disturbance was approximately modern in origin (ranging from $217 \pm 24{ }^{14} \mathrm{C}$ yr BP to modern in age; Table 3). In contrast, within-slump waters from site FM2 and FM3 were early Holocene-aged $(9592 \pm 64$, and $8167 \pm 39$ ${ }^{14} \mathrm{C}$ yr BP, respectively; Table 3). Slump runoff from site $\mathrm{SD}$ was older than at upstream sites but younger than for the larger slumps described above $\left(1157 \pm 23{ }^{14} \mathrm{C} \mathrm{yr} \mathrm{BP}\right.$; Table 3). 
Table 3. Measured fraction modern carbon $\left(\mathrm{F}^{14} \mathrm{C}\right)$ and estimated calendar years before present for ${ }^{14} \mathrm{C}$ of dissolved organic carbon samples collected upstream of, and within drainage waters of, selected slump sites. Data were collected during the summer of 2016 . "nc" indicates sample not collected. Error estimates indicate $1 \sigma$.

\begin{tabular}{lrrrrr}
\hline & \multicolumn{2}{c}{$\mathrm{F}^{14} \mathrm{C}$} & & \multicolumn{2}{c}{${ }^{14} \mathrm{C}$ yr BP } \\
\cline { 2 - 3 } \cline { 5 - 6 } Site & Upstream & Within-slump & & Upstream & Within-slump \\
\hline FM4 & $0.9734 \pm 0.0029$ & $\mathrm{nc}$ & & $217 \pm 24$ & $\mathrm{nc}$ \\
$\mathrm{FM} 2$ & $0.9764 \pm 0.0032$ & $0.3030 \pm 0.0024$ & & $192 \pm 27$ & $9592 \pm 64$ \\
FM3 & $1.0023 \pm 0.0030$ & $0.3618 \pm 0.0018$ & & modern & $8167 \pm 39$ \\
SD & $1.0216 \pm 0.0035$ & $0.8659 \pm 0.0025$ & & modern & $1157 \pm 23$ \\
\hline
\end{tabular}

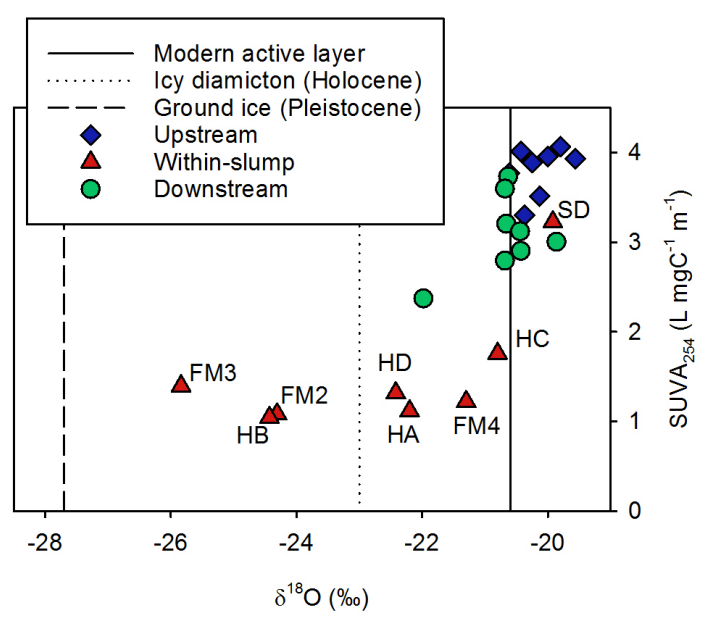

Figure 5. Paired oxygen isotopic $\left(\delta^{18} \mathrm{O} \%\right.$ o $)$ and $\mathrm{SUVA}_{254}$ $\left(\mathrm{L} \mathrm{mg} \mathrm{C} \mathrm{C}^{-1} \mathrm{~m}^{-1}\right.$ ) data, to demonstrate the relationship between source water age and dissolved organic matter composition. Reference $\delta^{18} \mathrm{O}$ values are from Lacelle et al. (2013): the modern activelayer value is derived from active-layer pore water in this region, icy diamicton has been sourced as Holocene in origin, and the $\delta^{18} \mathrm{O}$ value for Pleistocene-aged ground ice is the most positive value for this region.

\subsection{Patterns and environmental drivers of DOC flux}

Similar to our findings for the distributed sampling scheme (Fig. 2), downstream DOC concentration was consistently lower than concentrations upstream across the 19 paired measurements taken at the intensively studied site FM3 $(p<0.001, N=19, W=0$; Wilcoxon signed rank test; mean decline of $2.5 \pm 0.2 \mathrm{mg} \mathrm{L}^{-1}$, compared to a mean upstream concentration of $13.6 \pm 0.5 \mathrm{mg} \mathrm{L}^{-1}$ ). To explore environmental drivers of DOC movement within this landscape, however, we focus on DOC flux, which allows a direct assessment of slump-mediated DOC addition to this system. Downstream DOC flux $\left(\mathrm{mg} \mathrm{s}^{-1}\right)$ tended to be slightly greater than upstream flux on most, but not all, sampling occasions (Fig. 6). As a result, paired comparisons indicate no statistical difference between upstream and downstream DOC flux at this site (Wilcoxon signed rank test; $p=0.096, N=19$,
$W=53$ ). Because upstream and downstream fluxes were strongly correlated to one another $\left(r^{2}=0.94 ; p<0.0001\right)$, our downstream model was run without upstream DOC flux as a predictor variable. The best-fit multiple linear regression model for downstream DOC flux $\left(r^{2}=0.84 ; p<0.01\right)$ retained seven variables, of which two were significant (Table 4). Of these, air temperature ( $72 \mathrm{~h}$ prior to sampling) showed a negative relationship with downstream DOC flux, while rainfall $(0 \mathrm{~h}$; time of sampling) showed a strong positive relationship (Table 4). The best-fit model for upstream DOC flux $\left(r^{2}=0.87 ; p<0.001\right)$ also retained seven variables, of which four were significant $(p<0.05$; Table 4$)$. Similar to the downstream analysis, air temperature $(0,72 \mathrm{~h})$ displayed a negative relationship and time-of-sampling $(0 \mathrm{~h})$ rainfall a strong positive relationship with DOC flux (Table 4). However, $120 \mathrm{~h}$ rainfall showed a negative relationship with DOC flux in this model. Regressions assessing controls on downstream DOC flux relative to upstream flux (i.e., as a ratio or the difference between the two values) were not significant. Models to explore controls on upstream and downstream DOC concentration were also relatively similar to one another, showing strong, positive relationships between DOC concentration and air temperature and more modest negative relationships between DOC concentration and net radiation (Table 4).

\section{Discussion}

\subsection{Retrogressive thaw slumps and carbon delivery to streams of the Peel Plateau}

In both Eastern Siberia (Spencer et al., 2015; Vonk et al., 2013) and Alaska (Abbott et al., 2014) permafrost slumping has been associated with significant increases in DOC mobilization from terrestrial to aquatic systems. Our data show that this was not the case on the Peel Plateau, where the landscape-induced variation in DOC concentration among pristine stream sites was much greater than the change in stream water DOC as a result of slumping. Across all of our study sites, DOC concentrations consistently declined downstream of slumps when compared to upstream loca- 


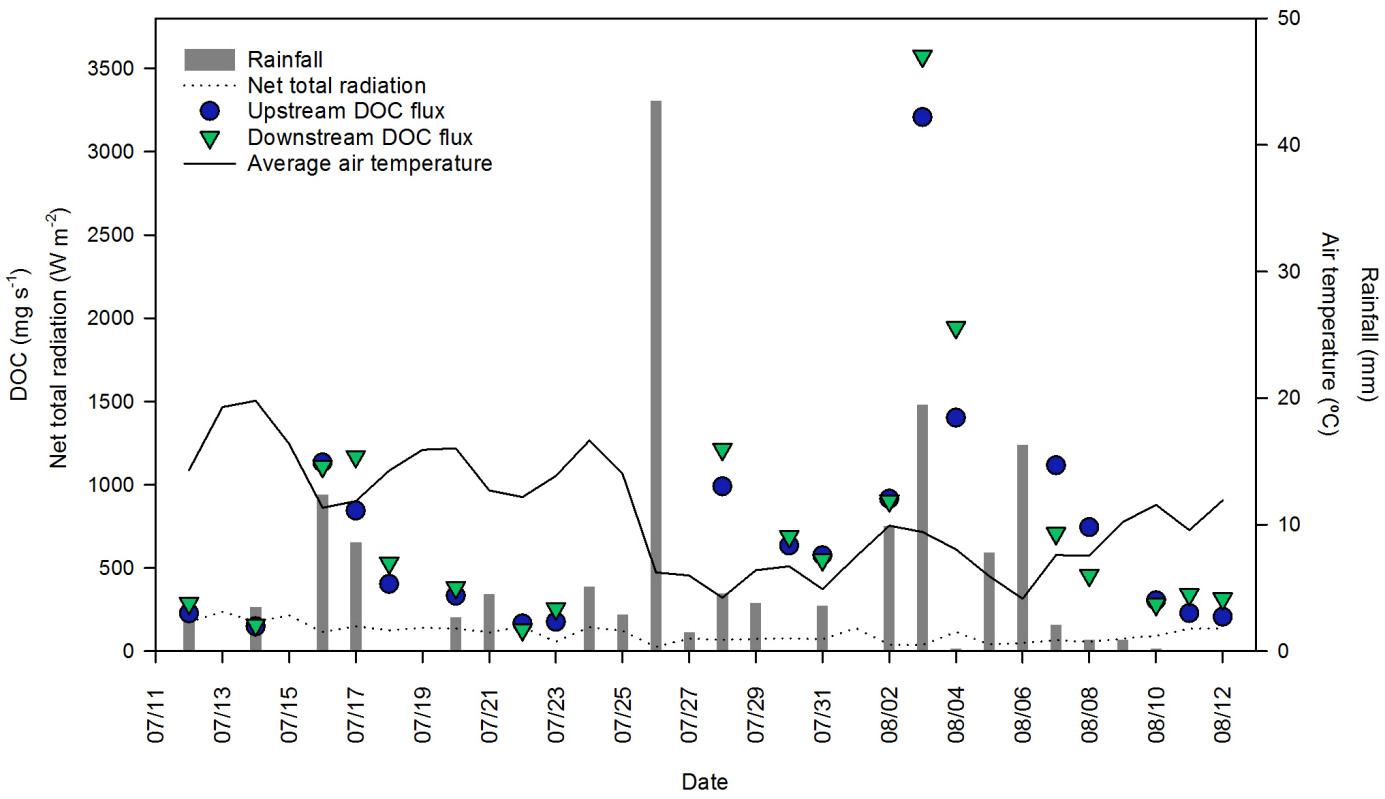

Figure 6. Environmental conditions (solar radiation, precipitation, and mean daily air temperature) and DOC flux upstream and downstream of slump FM3 across a month-long sample period (12 July-12 August 2014). Corresponding multiple linear regressions are described in Table 4.

Table 4. Results of multiple linear regression analyses to assess environmental controls on upstream and downstream DOC flux and upstream and downstream DOC concentration. "nr" indicates variables that were not retained in the best-fit regression model; NA indicates variables that were not run in individual analyses. Significant $p$ values are indicated with bold text; marginal results $(0.05<p<0.10)$ are indicated in italics. Model statistics are as follows: downstream flux $r^{2}=0.84, F_{7,11}=8.25, p=0.001$; upstream flux $r^{2}=0.87, F_{7,11}=10.79$, $p<0.001$; downstream concentration $r^{2}=0.85, F_{4,14}=19.57, p<0.001$; upstream concentration $r^{2}=0.91, F_{5,13}=27.05, p<0.001$.

\begin{tabular}{|c|c|c|c|c|c|c|c|c|c|c|c|c|}
\hline \multirow[b]{2}{*}{ Coefficient } & \multicolumn{3}{|c|}{$\begin{array}{l}\text { Downstream } \\
\text { DOC flux }\end{array}$} & \multicolumn{3}{|c|}{$\begin{array}{l}\text { Upstream } \\
\text { DOC flux }\end{array}$} & \multicolumn{3}{|c|}{$\begin{array}{c}\text { Downstream DOC } \\
\text { concentration }\end{array}$} & \multicolumn{3}{|c|}{$\begin{array}{l}\text { Upstream DOC } \\
\text { concentration }\end{array}$} \\
\hline & Estimate & $t$ & $p$ & Estimate & $t$ & $p$ & Estimate & $t$ & $p$ & Estimate & $t$ & $p$ \\
\hline \multicolumn{13}{|c|}{$\begin{array}{l}\text { Average Air Temperature } \\
\left({ }^{\circ} \mathrm{C}\right)\end{array}$} \\
\hline $0 \mathrm{~h}$ & -67.08 & -1.685 & 0.120 & -115.96 & -3.286 & 0.007 & $\mathrm{nr}$ & $\mathrm{nr}$ & $\mathrm{nr}$ & 0.165 & 2.349 & 0.035 \\
\hline $48 \mathrm{~h}$ & $\mathrm{nr}$ & $\mathrm{nr}$ & $\mathrm{nr}$ & 56.32 & 1.534 & 0.153 & 0.332 & 6.886 & $<0.001$ & 0.396 & 5.510 & $<0.001$ \\
\hline $72 \mathrm{~h}$ & -95.15 & -2.594 & 0.025 & -94.17 & -2.717 & 0.020 & & & & & & \\
\hline $120 \mathrm{~h}$ & $\mathrm{nr}$ & $\mathrm{nr}$ & $\mathrm{nr}$ & $\mathrm{nr}$ & $\mathrm{nr}$ & $\mathrm{nr}$ & 0.134 & 3.527 & 0.003 & 0.203 & 4.411 & $<0.001$ \\
\hline \multicolumn{13}{|l|}{ Rainfall (mm) } \\
\hline $0 \mathrm{~h}$ & 116.13 & 5.411 & $<0.001$ & 105.47 & 6.039 & $<0.001$ & -0.066 & -1.967 & 0.069 & $\mathrm{nr}$ & $\mathrm{nr}$ & $\mathrm{nr}$ \\
\hline $48 \mathrm{~h}$ & $\mathrm{nr}$ & $\mathrm{nr}$ & $\mathrm{nr}$ & $\mathrm{nr}$ & $\mathrm{nr}$ & $\mathrm{nr}$ & $\mathrm{nr}$ & $\mathrm{nr}$ & $\mathrm{nr}$ & $\mathrm{nr}$ & $\mathrm{nr}$ & $\mathrm{nr}$ \\
\hline $72 \mathrm{~h}$ & & $\mathrm{nr}$ & $\mathrm{nr}$ & & $\mathrm{nr}$ & $\mathrm{nr}$ & $\mathrm{nr}$ & $\mathrm{nr}$ & $\mathrm{nr}$ & $\mathrm{nr}$ & $\mathrm{nr}$ & $\mathrm{nr}$ \\
\hline $120 \mathrm{~h}$ & -23.94 & -1.970 & 0.075 & -24.15 & -2.529 & 0.028 & $\mathrm{nr}$ & $\mathrm{nr}$ & $\mathrm{nr}$ & $\mathrm{nr}$ & $\mathrm{nr}$ & $\mathrm{nr}$ \\
\hline \multicolumn{13}{|c|}{$\begin{array}{l}\text { Average net radiation } \\
\left(\mathrm{W} \mathrm{m}^{-2}\right)\end{array}$} \\
\hline $0 \mathrm{~h}$ & 4.96 & 1.286 & 0.225 & $\mathrm{nr}$ & $\mathrm{nr}$ & $\mathrm{nr}$ & -0.021 & -4.043 & 0.001 & -0.021 & -3.387 & 0.005 \\
\hline $48 \mathrm{~h}$ & $\mathrm{nr}$ & $\mathrm{nr}$ & $\mathrm{nr}$ & $\mathrm{nr}$ & $\mathrm{nr}$ & $\mathrm{nr}$ & $\mathrm{nr}$ & $\mathrm{nr}$ & $\mathrm{nr}$ & $\mathrm{nr}$ & $\mathrm{nr}$ & $\mathrm{nr}$ \\
\hline $72 \mathrm{~h}$ & 5.58 & 1.545 & 0.151 & 4.04 & 1.563 & 0.146 & $\mathrm{nr}$ & $\mathrm{nr}$ & $\mathrm{nr}$ & $\mathrm{nr}$ & $\mathrm{nr}$ & $\mathrm{nr}$ \\
\hline $120 \mathrm{~h}$ & $\mathrm{nr}$ & $\mathrm{nr}$ & $\mathrm{nr}$ & $\mathrm{nr}$ & $\mathrm{nr}$ & $\mathrm{nr}$ & $\mathrm{nr}$ & $\mathrm{nr}$ & $\mathrm{nr}$ & $\mathrm{nr}$ & $\mathrm{nr}$ & $\mathrm{nr}$ \\
\hline \multicolumn{13}{|c|}{$\begin{array}{l}\text { Total suspended solids } \\
\left(\mathrm{mg} \mathrm{L}^{-1}\right)\end{array}$} \\
\hline Downstream & -0.02 & -2.102 & 0.059 & NA & NA & NA & $\mathrm{nr}$ & $\mathrm{nr}$ & $\mathrm{nr}$ & NA & NA & NA \\
\hline Upstream & NA & NA & NA & -0.32 & -1.626 & 0.132 & NA & NA & NA & -0.0006 & -1.627 & 0.128 \\
\hline
\end{tabular}


tions, while at an intensively sampled slump, DOC flux did not differ significantly between upstream and downstream locations. In contrast, comparisons of channelized slump runoff (our within-slump sites) and paired unaffected sites showed no consistent DOC trend. Instead, DOC concentrations in slump runoff were either greater than, or less than, their comparison upstream locations in a manner that differed depending on slump morphological characteristics such as slump size and headwall height (Fig. 1; see further discussion in Sect. 5.3). The moderate effect of slumping on DOC concentration occurred despite the significant influence of these disturbances on the delivery of many biogeochemical constituents to recipient streams. For example, conductivity was approximately 1 order of magnitude greater and TSS 2 orders of magnitude greater in slump-derived runoff than at upstream, unaffected sites. This led to substantially increased TSS : DOC and $(\mathrm{Ca}+\mathrm{Mg})$ : DOC ratios downstream of slumps when compared to pristine, upstream locations.

Decreasing DOC concentrations downstream of slumps, despite increasing concentrations of indicators of slump activity (major ions, TSS), could be driven by several, potentially co-occurring factors. In some locations, decreases may be partially caused by low DOC concentrations in slump outflow (a dilution effect; see slumps FM2, FM3, and FM4 in Fig. 2; further discussed in Sect. 5.3). However, our results suggest that DOC sorption to suspended inorganic sediments could also play a role in regulating DOC dynamics in slump-affected systems. At multiple sites (HB, HC, and HD), DOC concentrations declined downstream of slumps despite a modest elevation in DOC concentration in slump drainage waters (Fig. 2). Thermokarst contributes significant amounts of fine-grained glacigenic sediment to fluvial systems on the Peel Plateau (Kokelj et al., 2013; silty-clay sediment classification for FM3 in Lacelle et al., 2013). DOC sorption can occur in seconds to minutes in freshwater systems (Qualls and Haines, 1992), with fine-grained materials being particularly conducive to this process (Kothawala et al., 2009). Data from site FM3, where we have upstream and downstream discharge data coupled with DOC and TSS concentrations at upstream, downstream, and within-slump locations on two separate dates, allow possible DOC sorption to be assessed. On these dates, DOC flux declined downstream of the slump (i.e., flux $x_{\text {DOCdown }}<$ flux $_{\text {DOCup }}$ ), despite a clear and measurable efflux of DOC from the slump to the receiving stream

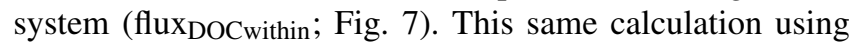
TSS as a rough tracer of slump inflow shows the calculated efflux of TSS from this slump (flux TSSwithin) to be almost identical to the increase in TSS flux downstream of the disturbance (as flux TSSdown-flux TSSup; Fig. 7). Thus, it seems likely that relatively rapid processes, such as sorption to mineral surfaces, are affecting DOC dynamics in thermokarstaffected fluvial systems on the Peel Plateau.

Although a similar decrease in DOC concentration with slumping has been found for lakes in this region (Kokelj et al., 2005), our findings contrast with those from other previ-

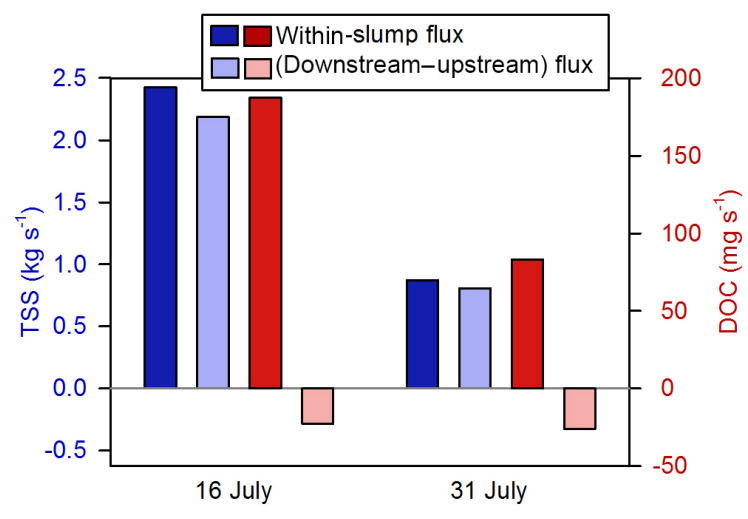

Figure 7. Within-slump fluxes of dissolved organic carbon (DOC) and TSS, compared to the calculated downstream-upstream fluxes for these two constituents.

ously studied areas of the Arctic, where thermokarst leads to an efflux of high-DOC waters from slump features (e.g., Abbott et al., 2014; Vonk et al., 2013). However, ice-marginal glaciated landscapes are common throughout the western Canadian Arctic and in many other Arctic regions. The thick, mineral-rich, carbon-poor tills with high ice contents that characterize these landscapes are predisposed to intense thaw slumping and the mobilization of glacigenic sediments from slope to stream (Kokelj et al., 2017a). As a result, DOC "sequestration" following slumping seems unlikely to be limited to the Peel Plateau. Given the high TSS export and apparent organic carbon sorption to glacigenic sediments observed with slumping on the Peel Plateau, we expect that substantial organic carbon is mobilized from these disturbances in the particle-attached, rather than dissolved, form (i.e., as particulate organic carbon, POC). Quantifying this POC mobilization and fate once subject to contemporary biogeochemical processing, and the mechanisms that enable DOC sequestration to occur, are key avenues for future research on the Peel Plateau and elsewhere.

\subsection{The effect of retrogressive thaw slumps on DOM composition}

Although DOC concentrations did not increase in RTSaffected streams, absorbance metrics clearly indicate that slump-derived DOM on the Peel Plateau is compositionally different than DOM from upstream locations. Upstream waters had significantly higher $\mathrm{SUVA}_{254}$ values than downstream and within-slump sites (Table 2, Fig. 4). Similarly, while the average $S_{\mathrm{R}}$ of Peel Plateau upstream waters $(0.74 \pm 0.005)$ was within the range of $S_{R}$ typically associated with fresh, terrestrial DOM $(\sim 0.70$; Helms et al., 2008), values were significantly greater within-slump $(0.92 \pm 0.015)$ and downstream $(0.89 \pm 0.009$; Table 2, Fig. 4), indicating decreasing DOM molecular weight as a result of RTS activity. High $\mathrm{SUVA}_{254}$ values accompanied 
by low $S_{\mathrm{R}}$ at upstream sites suggest that water flow in undisturbed catchments is restricted to shallow, organic-rich flow paths through the active layer, with permafrost inhibiting water contributions from deeper, groundwater or mineralassociated sources (Balcarczyk et al., 2009; MacLean et al., 1999; Mann et al., 2012; O’Donnell et al., 2010; Street et al., 2016). In contrast, within-slump and downstream measurements indicate a clear transition in DOM source.

The comparatively low $\mathrm{SUVA}_{254}$ and high $S_{\mathrm{R}}$ values for downstream and within-slump sites indicate that permafrostderived carbon on the Peel Plateau is characterized by relatively low molecular weight and aromaticity and is thus similar in its composition to permafrost carbon from other regions. For example, $\mathrm{SUVA}_{254}$ values were low in waters draining active thaw slumps when compared to stabilized and undisturbed sites on the North Slope of Alaska (Abbott et al., 2014), while in Siberia, ${ }^{14}$ C-depleted DOM from small tributary streams affected by thermokarst had lower $\mathrm{SUVA}_{254}$ values compared to younger DOM from the Kolyma River main stem (Mann et al., 2015; Neff et al., 2006). Although SUVA 254 values for waters draining Peel Plateau thaw slumps are slightly lower than those reported for Siberian yedoma disturbances (Mann et al., 2015), the overall similarity in permafrost-derived DOM composition across these various regions is striking, given the regional differences in permafrost origin and landscape history. For example, the DOM released by permafrost thaw on the Peel Plateau is till-associated and early Holocene in mean age, while east Siberian yedoma is composed of loess-derived Pleistocene deposits that sequestered carbon in association with syngenetic permafrost aggradation. This suggests that common processes may enable the organic matter contained in permafrost soils to become compositionally similar across diverse Arctic regions. Such compositional similarity also indicates that permafrost-origin DOM from the Peel Plateau similar to that from other regions (Abbott et al., 2014; Drake et al., 2015) - may be readily degraded by bacteria, despite the divergent origin of this carbon.

\subsection{The effect of slump morphometry on runoff water biogeochemistry}

$\delta^{18} \mathrm{O}$ and $\mathrm{DO}^{14} \mathrm{C}$ data provide further evidence that intense slumping enables novel sources of water and solutes to be transported to fluvial systems on the Peel Plateau. For most of the RTS features that we studied, the $\delta^{18} \mathrm{O}$ signature of within-slump waters ranged from similar to the icy diamicton that overlies the early Holocene thaw unconformity to that for underlying Pleistocene-aged ground ice (Lacelle et al., 2013; Fig. 5). Similarly, $\mathrm{DO}^{14} \mathrm{C}$ from a subset of sites indicates that slump-derived DOC is early Holocene in age for all but the shallowest slump surveyed. This suggests that our slump outflow samples were likely comprised of a mixture of Pleistocene-, Holocene-, and modern-sourced water (see Fig. 1c-e) but that the contribution of these end-members varied across slumps depending on the relative volume of the different stratigraphic units being mobilized.

The between-site variation in $\delta^{18} \mathrm{O}$ signature (Fig. 5) and relative DOC concentration (Fig. 2b) of slump runoff waters appears to be related to differences in slump morphometry (size, headwall height, and the length and area of the debris tongue; see Table 1 and Fig. 1c-e) across sites. The welldeveloped, larger slump complexes (FM4, FM2, and FM3) were more likely to have $\delta^{18} \mathrm{O}$ signatures that lie between end-member values for Holocene-aged icy diamicton and Pleistocene-aged ground ice (Fig. 5; although note that dry and stabilized FM4 differs somewhat from this trend). These well-developed slumps also stood out as displaying withinslump DOC concentrations that were lower than at upstream comparison sites (Fig. 2b). The headwall exposure at these largest slumps exposes Pleistocene-aged permafrost to several meters' depth (see Fig. 1c), while the evacuation of scar zone materials has produced extensive debris tongues up to several kilometers long (Table 1, Figs. 1b, S1e and S1g). This significant exposure of mineral-rich, Pleistocene-aged glacial till contributes solutes from low-carbon mineral soils and low-DOC ground ice (Fritz et al., 2015; Tanskii et al., 2016) to runoff, while entraining fine-grained sediments which provide mineral surface area for possible DOC adsorption. Adsorption may be further enhanced as slump and stream runoff continue to entrain sediments as flows incise the lengthy debris tongue deposits. In contrast, slumps with slightly shallower headwalls (HA, HB, HC, HD; see Fig. 1d) and less well-developed debris tongues (Table 1) appear to elicit a slightly different response than the largest slumps discussed above. At these midsized sites, within-slump DOC concentrations were typically higher than those found at upstream comparison sites (Fig. 2b), which may reflect the greater relative inputs from thawing of the Holocene-aged relict active layer, and decreased interaction with debris tongue deposits at these smaller disturbances. Similarly, runoff $\delta^{18} \mathrm{O}$ tends to lie between Holocene and modern end-member values at these sites (though note the more depleted value for HB; Fig. 5), indicating a lower relative contribution of Pleistocene-aged ground ice to slump outflow waters.

Finally, the youngest and shallowest slump surveyed (SD), exposed only near-surface permafrost soils for leaching and geochemical transport (Figs. 1e and S1; Table 1) and not the underlying mineral and ice-rich glacigenic substrates. Accordingly, the effects of slumping on stream chemistry, optical parameters, and isotopes were muted at SD when compared to the larger slumps discussed above. These morphometry-related shifts in the downstream effects of slumping suggest that we should expect nonlinearity in the biogeochemical response as RTS features develop over time, particularly if slumping continues to intensify with future warming on the Peel Plateau (e.g., Kokelj et al., 2017a; Rudy et al., 2017), underscoring the importance of long-term monitoring on the Peel Plateau and elsewhere. 


\subsection{Environmental controls on DOC flux and concentration}

Air temperature and rainfall exerted the strongest control on DOC flux at our intensively studied site, which was chosen to be representative of active Peel Plateau slumps eroding Holocene- to Pleistocene-aged sediments (slump FM3; Fig. 6; Table 4). Upstream of the slump, rainfall was positively correlated and air temperature negatively correlated with DOC flux. However, precipitation events were negatively related to temperature (Fig. 6), suggesting that over a single season, precipitation served as the primary environmental control on upstream DOC flux. DOC concentration was relatively constant with upstream discharge $(r=$ $-0.342, p=0.151)$, indicating that precipitation controlled DOC flux largely as a result of changes in runoff and that DOC was not source-limited over the timescale of our investigation. However, upstream DOC concentration was positively related to temperature (Table 4), suggesting a link between biological activity and within-soil DOC production (cf. Pumpanen et al., 2014). These upstream-of-slump results are consistent with work from other undisturbed permafrost and boreal regions, where precipitation and catchment runoff have been shown to control DOC flux in streams (Prokushkin et al., 2005; Pumpanen et al., 2014) and increasing temperature has been shown to increase DOC production in soils (Christ and David, 1996; Neff and Hooper, 2002; Prokushkin et al., 2005; Yanagihara et al., 2000). They are also consistent with the concept that the permafrost barrier forces runoff to travel through the shallow active layer, where high hydraulic conductivity leads to the rapid transport of carbon into fluvial systems (O’Donnell et al., 2010; Striegl et al., 2005).

Slumping did not significantly affect downstream DOC flux at the intensively studied slump site, when compared to DOC flux upstream (Fig. 6; Sect. 4.4). Although concentration consistently declined downstream at FM3 (Sect. 4.1 and 4.4), downstream DOC flux was either slightly higher or slightly lower than upstream flux; a result that seems likely to play out at other, comparable Peel Plateau slumps, given the coherent concentration patterns that we observed across this landscape. Concordant with the lack of slump effect on DOC flux, neither the ratio of, or the difference between, upstream and downstream DOC flux could be explained by any of our environmental variables, while the environmental controls on downstream flux were almost identical to those upstream (Table 4). The lack of clear environmental control on relative downstream: upstream DOC flux occurred despite the fact that precipitation has been shown to be a strong driver of sediment movement from slump features on the Peel Plateau, on timescales similar to those used for this work (Kokelj et al., 2015).

Considering the Peel Plateau landscape as a whole, it appears that precipitation serves as a primary, positive control on DOC flux. Thus, this study adds DOC production to the list of changes - such as increasing slump activity and sediment mobilization - that can be expected with the increased precipitation that is affecting this region and is predicted for many Arctic locations (IPCC, 2014; Kokelj et al., 2015). However, it appears that slumping does not override the landscape-scale control on DOC flux in this system - at least on the scale of this single-season - perhaps because processes like DOC sorption mask the influx of slump-derived DOC (Fig. 6). This result highlights the complexity of the interaction between changing climatic parameters and DOC dynamics on the Peel Plateau, where thaw slumps of increasing size mobilize till, glaciolacustrine, glaciofluvial, and organic deposits, while also draining contemporary active layers across a shrub tundra to spruce forest upland gradient. DOC dynamics are thus affected by both water and carbon generation across these variable landform types, while also being affected by biogeochemical interactions such as mineral adsorption in recipient systems. Future work to tease apart the interactions between changing climatic parameters, slump development, and resultant biogeochemical effects is clearly warranted, with the recognition that environmental controls on slump activity and the nature of the materials being thawed, and thus downstream biogeochemistry, can be expected to show marked regional variation (see, for example, work from Eureka Sound; Grom and Pollard, 2008).

\section{Conclusions: Dissolved carbon mobilization across diverse permafrost landscapes}

Carbon dynamics in Arctic aquatic systems are influenced by numerous factors, including geology, Quaternary and glacial history, soil composition, vegetation, active-layer dynamics, and the nature and intensity of thermokarst. As a result, the effect of permafrost thaw on DOC concentration and flux should - at a fundamental level - vary across broad, regional scales. Our results demonstrate that we can expect marked interregional variation in DOC transport to streams in response to permafrost degradation. For example, declines in DOC concentration downstream of slumps on the Peel Plateau clearly differ from what has been found in eastern Siberia and regions of Alaska, where thermokarst releases substantial quantities of DOC (e.g., Spencer et al., 2015), and increases DOC concentrations in downstream systems (Abbott et al., 2015). Efforts that incorporate information concerning the geology and Quaternary history of thawing landscapes, the physical and geochemical composition of permafrost soils, and the nature and intensity of thermokarst processes within landscapes (see, for example, Olefeldt et al., 2016) will considerably increase our ability to predict climate-driven changes in carbon delivery from land to water on a pan-Arctic scale.

On finer scales, this work underscores the variability of thermokarst effects within regions and the local-scale control on this variability. On the Peel Plateau, between-site differences in the biogeochemical effect of thermokarst are re- 
lated to variation in soil stratigraphy (i.e., the relative depth of the Holocene-aged paleo-thaw layer) and ever-evolving slump morphometry. Although striking within-region variability in biogeochemical response to thermokarst has been seen elsewhere (e.g., Watanabe et al., 2011), responses in other regions occur as a result of very different - and regionspecific - landscape-level drivers. This landscape specificity also extends to the nonlinear biogeochemical response as thermokarst features develop over time. Changes in downstream biogeochemistry with slump development are very different on the Peel Plateau, for example, than in other regions (e.g., Abbot et al., 2015), while temporal nonlinearity can also be expected for other types of permafrost thaw (Kokelj et al., 2002, Vonk et al., 2015a) such as increasing active-layer thickness (Romanovsky et al., 2010). It seems clear that a tiered approach, targeted within regions to understand local controls on thaw-driven DOC mobilization, and across regions to document the effects of broad-scale variation imposed by geological and climate legacy, is required to understand the future biogeochemical functioning of thermokarst-affected landscapes in a warming circumpolar Arctic.

Data availability. Data associated with this manuscript have been made available in Tables S1 and S2 in the Supplement.

\section{The Supplement related to this article is available online at https://doi.org/10.5194/bg-14-5487-2017-supplement.}

Competing interests. The authors declare that they have no conflict of interest.

Acknowledgements. Financial support for this research was provided by an Ontario Graduate Scholarship, the York University Fieldwork Cost Fund, the York University Research Cost Fund, the Northern Scientific Training Program, NSERC Discovery and Northern Research Supplement grants to Suzanne E. Tank, the Campus Alberta Innovates Program, and the Polar Continental Shelf Program. We would like to thank Scott Zolkos for his support as a field assistant and for the production of Fig. 1; Steven Tetlichi, Dustin Neyando, and Peter Snowshoe for field sampling assistance; and the Tetlit Gwich'in (Fort McPherson) Renewable Resources Council. Sarah Shakil and Scott Zolkos assisted with the collection of samples for $\mathrm{DO}^{14} \mathrm{C}$; Shawne Kokelj (Environment and Natural Resources, GNWT) provided meteorological data; Justin Kokoszka performed geospatial calculations of slump area and debris tongue length. Comments from Michael Fritz and one anonymous reviewer greatly improved the content of the manuscript. NWT Geological Survey contribution number 0107.

Edited by: Steven Bouillon

Reviewed by: Michael Fritz and one anonymous referee

\section{References}

Abbott, B. W., Larouche, J. R., Jones, J. B., Bowden, W. B., and Balser, A. W.: Elevated dissolved organic carbon biodegradability from thawing and collapsing permafrost, J. Geophys. Res., 119, 2049-2063, https://doi.org/10.1002/2014JG002678, 2014.

Abbott, B. W., Jones, J. B., Godsey, S. E., Larouche, J. R., and Bowden, W. B.: Patterns and persistence of hydrologic carbon and nutrient export from collapsing upland permafrost, Biogeosciences, 12, 3725-3740, https://doi.org/10.5194/bg-12-3725-2015, 2015.

Balcarczyk, K. L., Jones, J. B., Jaffé, R., and Maie, N.: Stream dissolved organic matter bioavailability and composition in watersheds underlain with discontinuous permafrost, Biogeochemistry, 94, 255-270, https://doi.org/10.1007/s10533-009-9324-x, 2009.

Battin, T. J., Kaplan, L. A., Findlay, S., Hopkinson, C. S., Marti, E., Packman, A. I., Newbold, J. D., and Sabater, F.: Biophysical controls on organic carbon fluxes in fluvial networks, Nat. Geosci., 1, 95-100, https://doi.org/10.1038/ngeo101, 2008.

Burn, C. R.: Cryostratigraphy, paleogeography, and climate change during the early Holocene warm interval, western Arctic coast, Canada, Can. J. Earth Sci., 34, 912-925, https://doi.org/10.1139/e17-076, 1997.

Burn, C. R. and Kokelj, S. V: The environment and permafrost of the Mackenzie Delta area, Permafrost Periglac., 20, 83-105, https://doi.org/10.1002/ppp.655, 2009.

Burnham, K. P. and Anderson, D. R.: Model Selection and MultiModel Inference: A Practical Information-Theoretic Approach, Springer, New York, 488 pp., 2002.

Chin, K. S., Lento, J., Culp, J. M., Lacelle, D., and Kokelj, S. V.: Permafrost thaw and intense thermokarst activity decreases abundance of stream benthic macroinvertebrates, Glob. Change Biol., 22, 2715-2728, https://doi.org/10.1111/gcb.13225, 2016.

Christ, M. J. and David, M. B.: Temperature and moisture effects on the production of dissolved organic carbon in a Spodosol, Soil Biol. Biochem., 28, 1191-1199, https://doi.org/10.1016/00380717(96)00120-4, 1996.

Curtin, J.: lmSupport: Support for Linear Models, R package version 2.9.2., 2015.

Dittmar, T. and Kattner, G.: The biogeochemistry of the river and shelf ecosystem of the Arctic Ocean: a review, Mar. Chem., 83, 103-120, https://doi.org/10.1016/S0304-4203(03)00105-1, 2003.

Drake, T. W., Wickland, K. P., Spencer, R. G. M., McKnight, D. M., and Striegl, R. G.: Ancient low-molecular-weight organic acids in permafrost fuel rapid carbon dioxide production upon thaw, P. Natl. Acad. Sci. USA, 112, 13946-13951, https://doi.org/10.1073/pnas.1511705112, 2015.

Duk-Rodkin, A. and Hughes, O. L.: Surficial Geology, Fort McPherson-Bell River, Yukon-Northwest Territories, Geological Survey of Canada, Map 1745A, scale 1:250 000, Geological Survey of Canada, Map 1745A, scale 1:250 000, 1992.

Durbin, J. and Watson, G. S.: Testing for serial correlation in least squares regression I, Biometrika, 37, 409-428, 1950.

Environment Canada: Canadian Climate Normals 1981-2010 Station Data, Fort McPherson, 2015.

Fox, J. and Weisberg, S.: An R Companion to Applied Regression, 2nd Edn., Thousand Oaks CA: Sage, 472 pp., 2009. 
Frey, K. E. and McClelland, J. W.: Impacts of permafrost degradation on arctic river biogeochemistry, Hydrol. Process., 23, 169182, https://doi.org/10.1002/hyp.7196, 2009.

Fritz, M., Wetterich, S., Schirrmeister, L., Meyer, H., Lantuit, H., Preusser, F., and Pollard, W. H.: Eastern Beringia and beyond: Late Wisconsinan and Holocene landscape dynamics along the Yukon Coastal Plain, Canada, Palaeogeogr. Palaeocl., 319-320, 28-45, https://doi.org/10.1016/j.palaeo.2011.12.015, 2012.

Fritz, M., Opel, T., Tanski, G., Herzschuh, U., Meyer, H., Eulenburg, A., and Lantuit, H.: Dissolved organic carbon (DOC) in Arctic ground ice, The Cryosphere, 9, 737-752, https://doi.org/10.5194/tc-9-737-2015, 2015.

Fritz, M., Vonk, J. E., and Lantuit, H.: Disappearing Arctic coastlines, Nat. Clim. Change, 7, 6-7, https://doi.org/10.1038/nclimate3188, 2017.

Green, S. A. and Blough, N. V.: Optical absorption and fluorescence properties of chromophoric dissolved organic matter in natural waters, Limnol. Oceanogr., 39, 1903-1916, https://doi.org/10.4319/lo.1994.39.8.1903, 1994.

Grom J. D. and Pollard W. H.: A study of High Arctic retrogressive thaw slump dynamics, Eureka Sound Lowlands, Ellesmere Island, in: Proceedings of the Ninth International Conference on Permafrost, Institute of Northern Engineering, edited by: Kane, D. L. and Hinkel, K. M., University of Alaska, Ninth International Conference on Permafrost, 545-550, 2008.

Hair, J. F. J., Anderson, R. E., Tatham, R. L., and Black, W. C.: Multivariate Data Analysis, 3rd Edn., Macmillan, New York, 1995.

Hedges, J. I., Keil, R. G., and Benner, R.: What happens to terrestrial organic matter in the ocean?, Org. Geochem., 27, 195-212, 1997.

Helms, J. R., Stubbins, A., Ritchie, J. D., Minor, E. C., Kieber, D. J., and Mopper, K.: Absorption spectral slopes and slope ratios as indicators of molecular weight, source, and photobleaching of chromophoric dissolved organic matter, Limnol. Oceanogr., 53, 955-969, https://doi.org/10.4319/lo.2008.53.3.0955, 2008.

Holmes, R. M., McClelland, J. W., Peterson, B. J., Tank, S. E., Bulygina, E., Eglinton, T. I., Gordeev, V. V., Gurtovaya, T. Y., Raymond, P. A., Repeta, D. J., Staples, R., Striegl, R. G., Zhulidov, A. V., and Zimov, S. A.: Seasonal and annual fluxes of nutrients and organic matter from large rivers to the Arctic Ocean and surrounding seas, Estuar. Coast., 35, 369-382, https://doi.org/10.1007/s12237-011-9386-6, 2012.

Hugelius, G., Strauss, J., Zubrzycki, S., Harden, J. W., Schuur, E. A. G., Ping, C. L., Schirrmeister, L., Grosse, G., Michaelson, G. J., Koven, C. D., O’Donnell, J. A., Elberling, B., Mishra, U., Camill, P., Yu, Z., Palmtag, J., and Kuhry, P.: Estimated stocks of circumpolar permafrost carbon with quantified uncertainty ranges and identified data gaps, Biogeosciences, 11, 6573-6593, https://doi.org/10.5194/bg-11-6573-2014, 2014.

IPCC: Topic 2: Future Climate Changes, Risks, and Impacts In Climate Change 2014: Synthesis Report, Contribution of Working Groups I, II and III to the Fifth Assessment Report of the Intergovernmental Panel on Climate Change edited by: Core Writing Team, Pachauri, R. K., and Meyer, L. A., IPCC, Geneva, Switzerland, 151 pp., Geneva, Switzerland, 2014.

Kaiser, K. and Guggenberger, G.: The role of DOM sorption to mineral surfaces in the preservation of organic matter in soils, Org. Geochem., 31, 711-725, https://doi.org/10.1016/S01466380(00)00046-2, 2000.
Khvorostyanov, D. V., Krinner, G., Ciais, P., Heimann, M., and Zimov, S. A.: Vulnerability of permafrost carbon to global warming. Part I: Model description and role of heat generated by organic matter decomposition, Tellus B, 60, 250-264, https://doi.org/10.1111/j.1600-0889.2007.00333.x, 2008a.

Khvorostyanov, D. V., Ciais, P., Krinner, G., Zimov, S. A., Corradi, C., and Guggenberger, G.: Vulnerability of permafrost carbon to global warming. Part II: Sensitivity of permafrost carbon stock to global warming, Tellus B, 60, 265-275, https://doi.org/10.1111/j.1600-0889.2007.00336.x, 2008b.

Kokelj, S. V. and Jorgenson, M. T.: Advances in thermokarst research, Permafrost Periglac., 24, 108-119, https://doi.org/10.1002/ppp.1779, 2013.

Kokelj, S. V., Smith, C. A., and Burn, C. R.: Physical and chemical characteristics of the active layer and permafrost, Herschel Island, western Arctic Coast, Canada, Permafrost Periglac., 13, 171-185, https://doi.org/10.1002/ppp.417, 2002.

Kokelj, S. V., Jenkins, R. E., Milburn, D., Burn, C. R., and Snow, N.: The influence of thermokarst disturbance on the water quality of small upland lakes, Mackenzie Delta region, Northwest Territories, Canada, Permafrost Periglac., 16, 343-353, https://doi.org/10.1002/ppp.536, 2005.

Kokelj, S. V., Lantz, T. C., Kanigan, J. C., Smith, S. L., and Coutts, R.: Origin and polycyclic behaviour of tundra thaw slumps, Mackenzie Delta region, Northwest Territories, Canada, Permafrost Periglac., 20, 173-184, https://doi.org/10.1002/ppp.642, 2009.

Kokelj, S. V., Lacelle, D., Lantz, T. C., Tunnicliffe, J., Malone, L., Clark, I. D., and Chin, K. S.: Thawing of massive ground ice in mega slumps drives increases in stream sediment and solute flux across a range of watershed scales, J. Geophys. Res.-Earth, 118, 681-692, https://doi.org/10.1002/jgrf.20063, 2013.

Kokelj, S. V., Tunnicliffe, J., Lacelle, D., Lantz, T. C., Chin, K. S., and Fraser, R.: Increased precipitation drives mega slump development and destabilization of ice-rich permafrost terrain, northwestern Canada, Global Planet. Change, 129, 56-68, https://doi.org/10.1016/j.gloplacha.2015.02.008, 2015.

Kokelj, S. V., Lantz, T. C., Tunnicliffe, J., Segal, R., and Lacelle, D.: Climate-driven thaw of permafrost preserved glacial landscapes, northwestern Canada, Geology, 45, 371-374, https://doi.org/10.1130/G38626.1, 2017a.

Kokelj, S. V, Tunnicliffe, J. F., and Lacelle, D.: The Peel Plateau of northwestern Canada: an ice-rich hummocky moraine landscape in transition, in Landscapes and Landforms of western Canada, edited by: Slaymaker, O., Springer International Publishing, Switzerland, 109-122, $2017 \mathrm{~b}$.

Kothawala, D. N., Moore, T. R., and Hendershot, W. H.: Soil properties controlling the adsorption of dissolved organic carbon to mineral soils, Soil Sci. Soc. Am. J., 73, 1831-1842, https://doi.org/10.2136/sssaj2008.0254, 2009.

Lacelle, D., Bjornson, J., and Lauriol, B.: Climatic and geomorphic factors affecting contemporary (1950-2004) activity of retrogressive thaw slumps on the Aklavik Plateau, Richardson Mountains, NWT, Canada, Permafrost Periglac., 21, 1-15, https://doi.org/10.1002/ppp.666, 2010.

Lacelle, D., Lauriol, B., Zazula, G., Ghaleb, B., Utting, N., and Clark, I. D.: Timing of advance and basal condition of the Laurentide Ice Sheet during the last glacial maximum in the 
Richardson Mountains, NWT, Quaternary Res., 80, 274-283, https://doi.org/10.1016/j.yqres.2013.06.001, 2013.

Lacelle, D., Fontaine, M., Forest, A. P., and Kokelj, S.: High-resolution stable water isotopes as tracers of thaw unconformities in permafrost: A case study from western Arctic Canada, Chem. Geol., 368, 85-96, https://doi.org/10.1016/j.chemgeo.2014.01.005, 2014.

Lacelle, D., Brooker, A., Fraser, R. H., and Kokelj, S. V.: Distribution and growth of thaw slumps in the Richardson MountainsPeel Plateau region, northwestern Canada, Geomorphology, 235, 40-51, https://doi.org/10.1016/j.geomorph.2015.01.024, 2015.

Lafrenière, M. J. and Lamoureux, S. F.: Thermal perturbation and rainfall runoff have greater impact on seasonal solute loads than physical disturbance of the active layer, Permafrost Periglac., 24, 241-251, https://doi.org/10.1002/ppp.1784, 2013.

Lang, S. Q., McIntyre, C. P., Bernasconi, S. M., Früh-Green, G. L., Voss, B. M., Eglinton, T. I., and Wacker, L.: Rapid 14C analysis of dissolved organic carbon in non-saline waters, Radiocarbon, 58, 505-515, https://doi.org/10.1017/RDC.2016.17, 2016.

Lantuit, H. and Pollard, W. H.: Fifty years of coastal erosion and retrogressive thaw slump activity on Herschel Island, southern Beaufort Sea, Yukon Territory, Canada, Geomorphology, 95, 84102, https://doi.org/10.1016/j.geomorph.2006.07.040, 2008.

Lantuit, H., Pollard, W. H., Couture, N., Fritz, M., Schirrmeister, L., Meyer, H., and Hubberten, H.W.: Modern and late Holocene retrogressive thaw slump activity on the Yukon Coastal Plain and Herschel Island, Yukon Territory, Canada, Permafrost Periglac., 23, 39-51, https://doi.org/10.1002/ppp.1731, 2012.

Lewkowicz, A. G.: Rate of short-term ablation of exposed ground ice, Banks Island, Northwest Territories, Canada, J. Glaciol., 32, 511-519, 1986.

Lewkowicz, A. G.: Headwall retreat of ground-ice slumps, Banks Island, Northwest Territories, Can. J. Earth Sci., 24, 1077-1085, https://doi.org/10.1139/e87-105, 1987.

MacLean, R., Oswood, M. W., Irons, J. G., and McDowell, W. H.: The effect of permafrost on stream biogeochemistry: A case study of two streams in the Alaskan (U.S.A.) taiga, Biogeochemistry, 47, 239-267, https://doi.org/10.1007/BF00992909, 1999.

Malone, L., Lacelle, D., Kokelj, S., and Clark, I. D.: Impacts of hillslope thaw slumps on the geochemistry of permafrost catchments (Stony Creek watershed, NWT, Canada), Chem. Geol., 356, 3849, https://doi.org/10.1016/j.chemgeo.2013.07.010, 2013.

Mann, P. J., Davydova, A., Zimov, N., Spencer, R. G. M., Davydov, S., Bulygina, E., Zimov, S., and Holmes, R. M.: Controls on the composition and lability of dissolved organic matter in Siberia's Kolyma River basin, J. Geophys. Res.-Biogeo., 117, G01028, https://doi.org/10.1029/2011JG001798, 2012.

Mann, P. J., Eglinton, T. I., McIntyre, C. P., Zimov, N., Davydova, A., Vonk, J. E., Holmes, R. M., and Spencer, R. G. M.: Utilization of ancient permafrost carbon in headwaters of Arctic fluvial networks, Nat. Commun., 6, 7856, https://doi.org/10.1038/ncomms8856, 2015.

McDowell, W. H.: Kinetics and mechanisms of dissolved organic carbon retention in a headwater stream, Biogeochemistry, 1, 329-352, 1985.

Murton, J. and French, H.: Cryostructures in permafrost, Tuktoyaktuk coastlands, western arctic Canada, Can. J. Earth Sci., 31, 737-747, https://doi.org/10.1139/e94-067, 1994.
Murton, J. B., Edwards, M. E., Lozhkin, A. V, Anderson, P. M., Savvinov, G. N., Bakulina, N., Bondarenko, O. V, Cherepanova, M. V, Danilov, P. P., Boeskorov, V., Goslar, T., Grigoriev, S., Gubin, S. V, Korzun, J. A., Lupachev, A. V, Tikhonov, A., Tsygankova, V. I., Vasilieva, G. V., and Zanina, O. G.: Preliminary paleoenvironmental analysis of permafrost deposits at Batagaika megaslump, Yana Uplands, northeast Siberia, Quaternary Res., 87, 314-330, https://doi.org/10.1017/qua.2016.15, 2017.

Neff, J. C. and Hooper, D. U.: Vegetation and climate controls on potential $\mathrm{CO} 2, \mathrm{DOC}$ and $\mathrm{DON}$ production in northern latitude soils, Glob. Change Biol., 8, 872-884, https://doi.org/10.1046/j.1365-2486.2002.00517.x, 2002.

Neff, J. C., Finlay, J. C., Zimov, S. A., Davydov, S. P., Carrasco, J. J., Schuur, E. A. G., and Davydova, A. I.: Seasonal changes in the age and structure of dissolved organic carbon in Siberian rivers and streams, Geophys. Res. Lett., 33, 1-5, https://doi.org/10.1029/2006GL028222, 2006.

Norris, D. K.: Geology of the northern Yukon and northwestern District of Mackenzie, Geological Survey of Canada, Map 1581A, scale 1:500 000, 1984.

O’Donnell, J. A., Aiken, G. R., Kane, E. S., and Jones, J. B.: Source water controls on the character and origin of dissolved organic matter in streams of the Yukon River basin, Alaska, J. Geophys. Res.-Biogeo., 115, 1-12, https://doi.org/10.1029/2009JG001153, 2010.

Olefeldt, D., Goswami, S., Grosse, G., Hayes, D., Hugelius, G., Kuhry, P., McGuire, A. D., Romanovsky, V. E., Sannel, A. B. K., Schuur, E. A. G., and Turetsky, M. R.: Circumpolar distribution and carbon storage of thermokarst landscapes, Nat. Commun., 7, 13043, 2016.

Palstra, S. and Meijer, H.: Biogenic carbon fraction of biogas and natural gas fuel mixtures determined with 14C, Radiocarbon, 56, 7-28, https://doi.org/10.2458/56.16514, 2014.

Pinheiro, J., Bates, D., DebRoy, S., Sarkar, D., and R Core Team: nlme: Linear and nonlinear mixed effects models, $\mathrm{R}$ package version 3.1-120, http://CRAN.R-project.org/package=nlme (last access: 28 October 2016), 2015.

Poulin, B. A., Ryan, J. N., and Aiken, G. R.: Effects of iron on optical properties of dissolved organic matter, Environ. Sci. Technol. 48, 10098-10106, https://doi.org/10.1021/es502670r, 2014.

Prokushkin, A. S., Kajimoto, T., Prokushkin, S. G., McDowell, W. H., Abaimov, A. P., and Matsuura, Y.: Climatic factors influencing fluxes of dissolved organic carbon from the forest floor in a continuous-permafrost Siberian watershed, Can. J. Forest Res., 35, 2130-2140, https://doi.org/10.1139/x05-150, 2005.

Pumpanen, J., A, L., Heli, M., Kolari, P., Ilvesniemi, H., Mammarella, I., Hari, O., Nikinmaa, E., Heinonsalo, J., Back, J., Ojala, A., Berninger, F., and Vesala, T.: Precipitation and net ecosystem exchange are the most important drivers of DOC flux in upland boreal catchments, J. Geophys. Res.-Biogeo., 119, 1861-1878, https://doi.org/10.1002/2014JG002705, 2014.

Qualls, R. and Haines, B. L.: Measuring adsorption isotherms using continuous, unsaturated flow through intact soil cores, Soil Sci. Soc. Am. J., 56, 456-460, https://doi.org/10.2136/sssaj1992.03615995005600020019x, 1992.

R Core Team: R: A Language and Environment for Statistical Computing, R Foundation for Statistical Computing, Vienna, Austria, http://www.r-project.org/ (last access: 28 October 2016), 2015. 
Rampton, V. N.: Quaternary geology of the Tuktoyaktuk coastlands, Northwest Territories, Geol. Surv. Canada, 1988.

Romanovsky, V. E., Smith, S. L., and Christiansen, H. H.: Permafrost thermal state in the polar Northern Hemisphere during the international polar year 2007-2009: a synthesis, Permafrost Periglac., 21, 106-116, https://doi.org/10.1002/ppp.689, 2010.

Rudy, A. C. A., Lamoureux, S. F., Kokelj, S. V., Smith, I. R., and England, J. H.: Accelerating thermokarst transforms ice-cored terrain triggering a downstream cascade to the ocean, Geophys. Res. Lett., 44, 11080-011087, 2017.

Schuur, E., Bockheim, J., Canadell, J. G., Euskirchen, E., Field, C. B., Goryachkin, S. V, Hagemann, S., Kuhry, P., Lafleur, P. M., Lee, H., Nelson, M. F. E., Rinke, A., Romanovsky, V. E., Shiklomanov, N., Tarnocai, C., Venevsky, S., Vogel, J. G., and Zimov, S. A.: Vulnerability of permafrost carbon to climate change?: Implications for the global carbon cycle, Bioscience, 58, 701-714, https://doi.org/10.1641/B580807, 2008.

Schuur, E. A. G., Abbott, B. W., Bowden, W. B., Brovkin, V., Camill, P., Canadell, J. G., Chanton, J. P., Chapin, F. S., Christensen, T. R., Ciais, P., Crosby, B. T., Czimczik, C. I., Grosse, G., Harden, J., Hayes, D. J., Hugelius, G., Jastrow, J. D., Jones, J. B., Kleinen, T., Koven, C. D., Krinner, G., Kuhry, P., Lawrence, D. M., McGuire, A. D., Natali, S. M., O’Donnell, J. A., Ping, C. L., Riley, W. J., Rinke, A., Romanovsky, V. E., Sannel, A. B. K., Schädel, C., Schaefer, K., Sky, J., Subin, Z. M., Tarnocai, C., Turetsky, M. R., Waldrop, M. P., Walter Anthony, K. M., Wickland, K. P., Wilson, C. J., and Zimov, S. A.: Expert assessment of vulnerability of permafrost carbon to climate change, Clim. Change, 119, 359-374, https://doi.org/10.1007/s10584013-0730-7, 2013.

Schuur, E. A. G., McGuire, A. D., Grosse, G., Harden, J. W., Hayes, D. J., Hugelius, G., Koven, C. D., and Kuhry, P.: Climate change and the permafrost carbon feedback, Nature, 520, 171-179, https://doi.org/10.1038/nature14338, 2015.

Segal, R. A., Lantz, T. C., and Kokelj, S. V: Acceleration of thaw slump activity in glaciated landscapes of the Western Canadian Arctic, Environ. Res. Lett., 11, 34025, https://doi.org/10.1088/1748-9326/11/3/034025, 2016.

Spencer, R. G. M., Mann, P. J., Dittmar, T., Eglinton, T. I., Mcintyre, C., Holmes, R. M., Zimov, N., and Stubbins, A.: Detecting the signature of permafrost thaw in Arctic rivers, Geophys. Res. Lett., 42, 2830-2835, https://doi.org/10.1002/2015GL063498, 2015.

Street, L. E., Dean, J. F., Billett, M. F., Baxter, R., Dinsmore, K. J., Lessels, J. S., Subke, J.-A., Tetzlaff, D., and Wookey, P. A.: Redox dynamics in the active layer of an Arctic headwater catchment; examining the potential for transfer of dissolved methane from soils to stream water, J. Geophys. Res.-Biogeo., 121, 27762792, https://doi.org/10.1002/2016JG003387, 2016.

Striegl, R. G., Aiken, G. R., Dornblaser, M. M., Raymond, P. A., and Wickland, K. P.: A decrease in dischargenormalized DOC export by the Yukon River during summer through autumn, Geophys. Res. Lett., 32, 1-4, https://doi.org/10.1029/2005GL024413, 2005.

Tank, S. E., Manizza, M., Holmes, R. M., McClelland, J. W., and Peterson, B. J.: The processing and impact of dissolved riverine nitrogen in the Arctic Ocean, Estuar. Coast., 35, 401-415, https://doi.org/10.1007/s12237-011-9417-3, 2012a.
Tank, S. E., Frey, K. E., Striegl, R. G., Raymond, P. A., Holmes, R. M., McClelland, J. W., and Peterson, B. J.: Landscapelevel controls on dissolved carbon flux from diverse catchments of the circumboreal, Global Biogeochem. Cy., 26, GB0E02, https://doi.org/10.1029/2012GB004299, 2012b.

Tanski, G., Couture, N., Lantuit, H., Eulenburg, A., and Fritz, M.: Eroding permafrost coasts release low amounts of dissolved organic carbon (DOC) from ground ice into the nearshore zone of the Arctic Ocean, Glob. Biogeochem. Cy., 30, 1054-1068, https://doi.org/10.1002/2015GB005337, 2016.

Tanski, G., Lantuit, H., Ruttor, S., Knoblauch, C., Radosavljevic, B., Strauss, J., Wolter, J., Irrgang, A. M., Ramage, J., and Fritz, M.: Transformation of terrestrial organic matter along thermokarstaffected permafrost coasts in the Arctic, Sci. Total Environ., 581582, 434-447, https://doi.org/10.1016/j.scitotenv.2016.12.152, 2017.

Thompson, M. S., Prowse, T. D., Kokelj, S. V., and Wrona, F. J.: The impact of sediments derived from thawing permafrost on tundra lake water chemistry: An experimental approach, Proc. Ninth Int. Conf. Permafr., 29, 1763-1768, 2008.

Vonk, J. E. and Gustafsson, Ö.: Permafrost-carbon complexities, Nat. Geosci., 6, 675-676, https://doi.org/10.1038/ngeo1937, 2013.

Vonk, J. E., Mann, P. J., Davydov, S., Davydova, A., Spencer, R. G. M., Schade, J., Sobczak, W. V., Zimov, N., Zimov, S., Bulygina, E., Eglinton, T. I., and Holmes, R. M.: High biolability of ancient permafrost carbon upon thaw, Geophys. Res. Lett., 40, 2689 2693, https://doi.org/10.1002/grl.50348, 2013.

Vonk, J. E., Tank, S. E., Bowden, W. B., Laurion, I., Vincent, W. F., Alekseychik, P., Amyot, M., Billet, M. F., Canário, J., Cory, R. M., Deshpande, B. N., Helbig, M., Jammet, M., Karlsson, J., Larouche, J., Macmillan, G., Rautio, M., Walter Anthony, K. M., and Wickland, K. P.: Reviews and syntheses: Effects of permafrost thaw on Arctic aquatic ecosystems, Biogeosciences, 12 7129-7167, https://doi.org/10.5194/bg-12-7129-2015, 2015a.

Vonk, J. E., Tank, S. E., Mann, P. J., Spencer, R. G. M., Treat, C. C., Striegl, R. G., Abbott, B. W., and Wickland, K. P.: Biodegradability of dissolved organic carbon in permafrost soils and aquatic systems: a meta-analysis, Biogeosciences, 12, 69156930, https://doi.org/10.5194/bg-12-6915-2015, 2015 b.

Ward, R. C. and Robinson, M.: Principles of Hydrology, Fourth Edition, McGraw-Hill International (UK) Limited, 2000.

Watanabe, S., Laurion, I., Chokmani, K., Pienitz, R., and Vincent, W. F.: Optical diversity of thaw ponds in discontinuous permafrost: A model system for water color analysis, J. Geophys. Res.-Biogeo., 116, G02003, https://doi.org/10.1029/2010JG001380, 2011.

Weishaar, J. and Aiken, G.: Evaluation of specific ultra-violet absorbance as an indicator of the chemical content of dissolved organic carbon, Environ. Chem., 37, 4702-4708, https://doi.org/10.1021/es030360x, 2003.

Yanagihara, Y., Koike, T., Matsuura, Y., Mori, S., Shibata, H., Satoh, F., Masuyagina, O., Zyryanova, O., Prokushkin, A. S., Prokushkin, S. G., and Abaimov, A. P.: Soil respiration on the contrasting north- and south-facing slopes of a larch forests in Central Siberia, Eurasian J. For. Res., 1, 19-29, 2000. 
Zeileis, A. and Grothendieck, G.: zoo: S3 infrastructure for regular and irregular time series, J. Stat. Softw., 14, 1-27, 2005.

Zeileis, A. and Hothorn, T.: Diagnostic checking in regression relationships, R News, 2, 7-10, 2002.

Zhou, Y., Guo, H., Lu, H., Mao, R., Zheng, H., and Wang, J.: Analytical methods and application of stable isotopes in dissolved organic carbon and inorganic carbon in groundwater, Rapid Commun. Mass Spectrom., 29, 1827-1835, https://doi.org/10.1002/rcm.7280, 2015.
Zuur, A. F., Ieno, E. N., Walker, N., Saveliev, A. A., and Smith, G. M.: Mixed Effects Models and Extensions in Ecology with R, Springer, New York, 574 pp., 2009. 